\title{
The Neural Plasticity Theory of Depression: Assessing the Roles of Adult Neurogenesis and PSA-NCAM within the Hippocampus
}

\author{
Steven R. Wainwright and Liisa A. M. Galea \\ Program in Neuroscience, Centre for Brain Health, Department of Psychology, University of British Columbia, \\ Vancouver, BC, Canada V6T $1 Z 4$ \\ Correspondence should be addressed to Liisa A. M. Galea; lgalea@psych.ubc.ca
}

Received 5 February 2013; Accepted 13 March 2013

Academic Editor: Chitra D. Mandyam

Copyright (C) 2013 S. R. Wainwright and L. A. M. Galea. This is an open access article distributed under the Creative Commons Attribution License, which permits unrestricted use, distribution, and reproduction in any medium, provided the original work is properly cited.

\begin{abstract}
Depression is a devastating and prevalent disease, with profound effects on neural structure and function; however the etiology and neuropathology of depression remain poorly understood. Though antidepressant drugs exist, they are not ideal, as only a segment of patients are effectively treated, therapeutic onset is delayed, and the exact mechanism of these drugs remains to be elucidated. Several theories of depression do exist, including modulation of monoaminergic neurotransmission, alterations in neurotrophic factors, and the upregulation of adult hippocampal neurogenesis, and are briefly mentioned in the review. However none of these theories sufficiently explains the pathology and treatment of depression unto itself. Recently, neural plasticity theories of depression have postulated that multiple aspects of brain plasticity, beyond neurogenesis, may bridge the prevailing theories. The term "neural plasticity" encompasses an array of mechanisms, from the birth, survival, migration, and integration of new neurons to neurite outgrowth, synaptogenesis, and the modulation of mature synapses. This review critically assesses the role of adult hippocampal neurogenesis and the cell adhesion molecule, PSA-NCAM (which is known to be involved in many facets of neural plasticity), in depression and antidepressant treatment.
\end{abstract}

\section{Neural Plasticity and Disease}

As the fundamental units of the brain, neurons function to integrate and transmit a myriad of signals across vast and complex networks. Neurons by definition are continually forming, eliminating, and modulating (strengthening and weakening) connections in response to the constant flow of information. In mediating and responding to activity, neurons, including their processes and synapses, must be plastic. Thus neural plasticity may then be defined as the ability of neurons and neural elements to adapt in response to intrinsic and extrinsic signals. As such, our ability to process and synthesize information, ultimately producing behavior, is dependent upon this neural plasticity [1]. It is therefore not surprising that dysregulation or disruption of neural plasticity is associated with neuropsychiatric and neurodegenerative disease.

Dynamic processes such as adult neurogenesis, the development of dendritic spines, and synaptic adaptations are included under the umbrella of neural plasticity and are essential to normal functioning. Aberrant neural production, connectivity, or transmission is invariably present under disease states, such as Alzheimer's disease, schizophrenia, or depression [2-5]. Each aspect of neural plasticity can independently and additively cause or contribute to the disease state. Thus, it is of fundamental importance to elucidate the neurological underpinnings of these disease states at the cellular level, in order to understand etiology and better develop effective treatment.

\section{Adult Hippocampal Neurogenesis}

Neural stem cells were first identified in the adult brain of rodents more than 50 years ago [6] and are found across a variety of species including humans [7]. Interestingly, the production of new neurons is typically limited to two regions: the subventricular zone, which lines the lateral ventricles and sends new neurons to the olfactory bulb via the rostral migratory stream, and the subgranular zone of the hippocampus [8]. 
It is important to note that neurogenesis, as defined here, requires the proliferation, survival, and differentiation of newly generated cells into neurons. Any number of internal and/or external factors may independently affect the proliferation of progenitor cells, their differentiation into neurons, or their survival rates [9-14]. Thus merely identifying cells as having been produced in the adult brain, without further demonstrating that they survive and become neurons, is insufficient to conclude that neurogenesis has occurred.

Although new neurons can be labelled and observed, the exact role of these neurons in the function of the hippocampus remains to be fully elucidated. New neurons produced in the subgranular zone have been associated with a number of functions $[15,16]$. There is solid evidence that new hippocampal neurons are selectively and imperatively involved in spatial learning and memory [17-20]. New neurons in the hippocampus, perhaps more ambiguously, have also been associated with the etiology and treatment of depression [2123]. Interestingly, the hippocampus is functionally dissociated along the dorsal-ventral axis, wherein the dorsal region plays a larger role in cognitive faculties, while the ventral region is more involved in emotionality [24, 25]. For the purpose this review, however, we will concentrate on the functions of the hippocampus associated with emotionality and stress and refer the reader to reviews that cover the hippocampus' cognitive associations (See: $[26,27]$ ).

\section{Cell Adhesion Molecules}

Neural plasticity is a complex and varied process; from neural development, the migration of newly generated neurons, dendritic modifications, and synaptic modulation, many proteins facilitate and contribute to the malleability of neural tissue. Cell adhesion molecules (CAMs) are specialized proteins - typically expressed at the cell surface-which are important in synaptic function, synaptic plasticity, and remodeling of neural circuits [28]. The structure and function of CAMs vary widely within the nervous system, and the categorization and function of each CAM protein involved in neural plasticity are beyond the scope of this review (for a more detailed overview see $[28,29])$. This review will instead focus on the potential role of a single CAM, the polysialylated form of neural cell adhesion molecule (PSA-NCAM), in the etiology and treatment of depression.

The neural cell adhesion molecule (NCAM) is a member of the immunoglobulin superfamily of cell adhesion molecules and serves to mediate $\mathrm{Ca}^{+}{ }^{+}$-independent cellcell and cell-extracellular matrix (ECM) interactions [30]. Through homo- and heterophilic interactions, NCAM functions in cell migration, neurite outgrowth and targeting, axonal branching, synaptogenesis, and synaptic plasticity [30-32]. Neural plasticity mediated through the NCAM protein is facilitated through posttranslational modifications, the most important and prevalent of which is glycosylation with polysialic acid (PSA) [33]. Polysialic acid is a linear homopolymer of $\alpha 2,8$-linked sialic acid, which bears a negative charge, acting to abate NCAM-NCAM interactions and therefore interfere with cell adhesion [34]. PSA-NCAM serves to regulate cell-cell and cell-ECM interactions during times of plasticity.

In the adult brain PSA-NCAM is expressed on the cell surface of newly generated daughter cells, on neurites during outgrowth and path finding, and at the synapse of mature neurons [30]. The addition of the PSA moiety to NCAM is essential to neural remodelling and synaptic plasticity [10, $35,36]$. Selective cleavage of PSA in the adult brain inhibits activity-induced synaptic plasticity (induction of long-term potentiation (LTP) and long-term depression (LTD)) and alters the normal migration and integration of newly generated neurons within the hippocampus [10, 35], importantly though cleavage of PSA from NCAM does not disrupt normal basal synaptic neurotransmission or alter normal levels of neural proliferation or survival $[10,35]$. PSA-NCAM is therefore a particularly interesting protein in that it is one that mediates plasticity at multiple levels, from neural proliferation, integration, differentiation, neuritic outgrowth, synaptogenesis, and modulation of mature synapses.

\section{Depression}

Depression is a devastating neuropsychiatric disease that is both prevalent - with a lifetime incidence of 20\% [37] — and costly, accruing over $\$ 83$ billion (USD) annually in expense to society in the USA alone [38]. Depression is a spectrum disorder ranging from dysthymia to major depressive disorder (MDD), which also includes seasonal (seasonal affective disorder) and bipolar subtypes; however general symptomology is characterized by a depressed mood and/or anhedonia [39]. The DSM-IV criteria for diagnosis with MDD may include secondary symptoms such as fatigue, insomnia or hypersomnia, changes in body weight, and impaired cognition [39]. Although depression is prevalent and carries a large burden of disease, the pathoetiology of depression is poorly understood. While antidepressant drugs do exist, they are not ideal, as only a segment of patients is effectively treated, and the therapeutic onset is delayed [40-42]. Moreover, the exact mechanism of these drugs remains to be elucidated, though several theories do exist. The existing theories of etiology and treatment of depression will be briefly discussed with an aim of integrating and placing neurogenesis and PSA-NCAM related plasticity within the current state of knowledge.

\section{Monoamine Theory of Depression}

Much of the current understanding of depression has been built upon the serendipitous discovery of the mood-elevating effects of iproniazid, a monoamine oxidase inhibitor (MAOI), during clinical trials for antituberculosis agents in the early 1950s $[43,44]$. Around the same time the first tricyclic antidepressant (TCA), imipramine, a drug also known to modulate monoaminergic neurotransmission, was discovered to relieve depressive symptoms [45]. Both compounds enhance monoaminergic neurotransmitters (primarily serotonin and norepinephrine) function in the synapse and therefore acted as a springboard for the rational design of drugs which specifically enhance the transmission of these neuromodulators. Further, these findings resulted in the development 
of the monoamine hypothesis of depression [46, 47]. The monoamine hypothesis of depression postulates that the pathophysiological basis of depression is due to the deficient activity of monoamines in the central nervous system [48].

While first generation antidepressant drugs can indeed be effective, remission rates still typically remain below $60 \%$, and treatment is associated with potentially severe side effects, causing a third of patients to discontinue treatment $[49,50]$. Thus new drugs, such as selective serotonin reuptake inhibitors (SSRIs), have been developed in an attempt to enhance efficacy and reduce the side effects observed with the broader-acting first generation compounds. However, the ability of these newer drugs to alleviate depression is, unfortunately, typically lower than that of MAOIs and TCAs [50]. SSRIs are the primary first line treatment for patients with major depressive disorder (MDD), yet only a third of patients will respond to these drugs following initial treatment [41]. Even in patients that are initially responsive to treatment, up to $57 \%$ will have depressive symptoms return due to a loss of drug efficacy [40].

While it is known that antidepressants modify monoaminergic neurotransmission, it is not known how antidepressants exert their therapeutic effects, as the influence on monoamines occurs within hours of treatment, but alleviation of depressive symptoms requires weeks of exposure [5154]. The monoamine theory explains this delayed efficacy of treatment as the time required for the 5-HT1A serotonin autoreceptor to sensitize and normalize serotonergic tone at the synapse $[42,55,56]$. However, disrupting or ablating portions of the serotonergic system fails to induce a depressive phenotype [57], suggesting that the dysregulation of serotonergic neurotransmission is not the only underlying factor in depression. Given the prevalence of treatment-resistant forms of depression and the limited long-term efficacy of current drugs, novel targets are needed for the development of more efficacious pharmacological treatments.

\section{Neurogenic Hypothesis of Depression}

As noted earlier, neurogenesis in the adult hippocampus is seen across a variety of species, including humans [7]. Adult hippocampal neurogenesis has been hypothesized to play a potentially important role on the pathology and successful treatment of depression. A neurogenic hypothesis of depression has been postulated, which suggests that reduced adult hippocampal neurogenesis may underlie the pathoetiology of depression, while antidepressant efficacy depends on the upregulation of hippocampal neurogenesis [58].

\section{Etiology of Depression and Animal Models}

As with other neuropsychiatric disorders, depression has a multifaceted and varied etiology, including genetic, epigenetic, and environmental factors. The most prevalent of these factors is stress. Stress is cited as the leading cause of depression by depressed patients [59]. Unipolar depression is associated with abnormal hypothalamic-pituitary adrenal (HPA) axis function such as hypersecretion of cortisol, abnormal diurnal secretion of cortisol resulting in a flattened circadian rhythm and impaired negative feedback $[59,60]$. Interestingly, normalization of HPA function is seen after chronic exposure to antidepressants, an effect coincident with, or slightly preceding, behavioural alleviation of depressive symptoms [61]. As such normalization of HPA function has become a major target of novel therapies [59,62].

Many animal models of depression capitalize on the association of stress and depression; such models have a solid ethological basis. For instance, models using exposure to chronic variable stress (CVS) have shown good face, construct, and predictive validity, making it one of the most commonly used paradigms to model depression [63]. For example, CVS increases immobility in the forced swim test (FST, a putative measure of behavioural despair) [64], reduces sucrose preference (anhedonia) [65], increases noveltyinduced hypophagia $[21,64]$, reduces hippocampal neurogenesis $[21,65]$, and reduces the expression of proteins associated with neuroplasticity such as PSA-NCAM [66]. Although it is not possible to model all symptoms of depression in rodents, a battery of key endophenotypes can be examined such as anhedonia, body weight changes, behavioural despair, HPA function, and brain alterations (such as reduced hippocampal volume, neurogenesis, and neural plasticity), as have been observed in human patients with depression [67].

\section{Stress, Depression, and Reduced Neural Plasticity}

The hippocampal formation is an area rich in mineralocorticoid (MRs) and glucocorticoid receptors (GRs). These receptors function in the maintenance of basal HPA tone and in the regulation of negative feedback of glucocorticoid release during a stress response [68]. Given this, it is not surprising that the hippocampus is particularly vulnerable to the effects of stress and depression [69, 70]. Depressed patients have reduced hippocampal volume which varies with the number of episodes and duration of the illness [7173]. Similarly, postmortem studies of hippocampal tissue collected from depressed patients have shown alterations in gray matter density, reductions in neuropil, and decreased hippocampal neurogenesis [22, 23, 74-77]. Animal models of depression using exposure to chronic stress demonstrate the same changes in hippocampal structure and show reductions in neural plasticity, including reductions in neurogenesis and the expression of proteins associated with neural plasticity $[21,64,65,78]$. Chronic stress exposure also reduces dendrite length and complexity $[79,80]$, spine density [81], and NCAM expression [65] and modifies expression of synaptic SNARE proteins [82] in the hippocampus.

Stabilization of the HPA axis by antidepressants is associated with improved mood scores that either precedes or is coincident with the behavioural alleviation of depressive symptoms in humans [61]. Thus the improvements in negative feedback inhibition of the HPA axis that correspond to improvement in depressive symptoms with antidepressant treatment may be attributable to neural adaptation in limbic structures that regulate feedback inhibition of HPA axis such as the hippocampus. Interestingly chronic antidepressant treatment is seen to reverse the negative effects of stress on 
hippocampal volume $[65,83]$, though the exact contribution of neural plastic elements that underlie this enhancement is not fully understood.

\section{Neurogenesis in Antidepressant Efficacy}

The neurogenic hypothesis of depression is predicated not only on the previous findings that chronic stress decreases hippocampal neurogenesis $[21,65,84]$ but also that antidepressant drugs can both prevent $[83,85]$ and reverse [21, $65,86]$ this effect (see Table 1). The enhancement of adult hippocampal neurogenesis is dependent on chronic, but not acute, exposure to antidepressants, occurring in a manner that temporally coincides with the delayed clinical efficacy of these drugs $[9,21]$. This delayed enhancement of neurogenesis is mediated through the increased proliferation of neural progenitor cells, while the proportion and the differentiation of surviving cells into neurons remain constant [9]. Several classes of antidepressant including SSRIs, TCAs, MAOIs, SNRIs, and melatonergic antidepressants increase neurogenesis in the hippocampus $[87,88]$. Moreover, the nonpharmacological antidepressant treatment of electroconvulsive therapy (ECT) also enhances neurogenesis in the adult hippocampus $[89,90]$. ECT is the most effective antidepressant treatment in depressed patients who are treatment resistant [91], and it can upregulate neurogenesis to levels nearly twice that of pharmacological antidepressants [89]. Similarly, recent human studies suggest that the broader acting, typically more efficacious, TCA and MAOI classes of antidepressant increase cell proliferation levels beyond that of SSRIs [23]; further indicating a role for hippocampal neurogenesis in successful antidepressant treatment.

While it is accepted that chronic antidepressant treatment upregulates hippocampal neurogenesis, some studies have suggested that increased neurogenesis is absolutely necessary for antidepressant efficacy. Specifically, if hippocampal neurogenesis is reduced via localized irradiation, antidepressants lose their behavioural efficacy in rodent models of depression [21]. However, use of the cytostatic agent methylazoxymethanol (MAM) to reduce hippocampal neurogenesis failed to disrupt the behavioural efficacy of chronic antidepressant treatment on sucrose preference or in the forced swim test; antidepressant treatment still increased hippocampal volume and NCAM expression, despite the disruption of hippocampal neurogenesis [65]. Nonetheless, neurogenesis does seem to be required for the attenuation of anxiety-like behaviour as measured in the novelty suppressed feeding (NSF) test, suggesting a role for neurogenesis in specific aspects of antidepressant efficacy. Indeed, further research has shown neurogenic-dependent and -independent effects of an antidepressant drug, where hippocampal neurogenesis is only required for the alleviation of some anxiety/depressive-like behaviour [64, 92-94]. These findings point toward multifaceted and pleiotropic effects of antidepressants on neural circuitry. Interestingly anxiolytic drugs, such as benzodiazepines, also show efficacy in the NSF test with acute treatment, while antidepressants require chronic, neurogenesisenhancing treatment [95]. It is then possible that the reduction in glucocorticoids from anxiolytic treatment mediates the reduction in anxiety-like behaviour in the NSF test; therefore antidepressant-induced neurogenesis may mediate a similar effect on glucocorticoid levels. Indeed this may be the case, as hippocampal neurogenesis buffers the stress response and normalizes glucocorticoid release after stress [96]. Synder and colleagues found that inhibition of hippocampal neurogenesis, either transgenically or via irradiation, attenuated the recovery of basal HPA tone following a stressor and the normal suppression of glucocorticoid release during the dexamethasone suppression test [96]. As such, there is likely a role for hippocampal neurogenesis in reestablishing normal HPA tone and regulating a normal HPA response, possibly through GR-mediated negative feedback. Thus the effectiveness of antidepressant treatment and the importance of ensuing neurogenesis within different behavioural measures of antidepressant efficacy may represent the underlying mechanisms through which antidepressants are exerting their effects. Separate facets of antidepressant-induced neural plasticity may therefore facilitate drug action such as neurogenesis-mediated normalization of the stress response in the NSF test versus modulation of monoaminergic tone through synaptic plasticity in the sucrose preference test and FST. Hence the contribution of broader neural plasticity, beyond neurogenesis, is also of interest and has been proposed as the underlying mechanism of antidepressant efficacy [65].

\section{Potential Role for PSA-NCAM in Antidepressant Efficacy}

The expression of PSA-NCAM within the adult nervous system is essential in multiple facets of neural plasticity, including neurogenesis, synaptic plasticity, and neurite outgrowth $[10,30,31,97,98]$. Importantly, PSA-NCAM functions across all aspects of hippocampal neurogenesis (proliferation, migration, differentiation, and survival), therefore changes in the polysialylation of newly generated neurons alter neurogenesis as a whole [99-104] (see Table 2). For instance, chronic mild stress reduces the expression of both the core NCAM protein [65] and the addition of the PSA moiety [11, 105-108] in the hippocampus; however these changes are dependent on the type of stressor [109] (see Table 3). Alterations in PSA-NCAM expression following stress are also seen in other regions associated with depression including the amygdala and prefrontal cortex [110-113]. Similarly, PSA-NCAM expression is reduced in amygdala of patients with major depressive disorder [2, 114]; however no change is seen in the PFC [115]. Conversely, chronic antidepressant treatment modulates PSA-NCAM expression throughout the limbic system in animal models of depression. [11, 116-119]. Moreover, antidepressant treatment reduces PSA-NCAM expression in the dorsal raphe nucleus [116], implicating PSA-NCAM in antidepressant-induced plasticity related to serotonergic neurotransmission. Taken together these findings suggest PSA-NCAM may play a fundamental role in mediating broad effects of antidepressant treatment across multiple forms of neural plasticity.

Previous studies have shown PSA-NCAM is essential in the activity-dependent induction of hippocampal LTP and 
TABLE 1: Selected publications showing the effect of stress/depression or antidepressant treatment on neurogenesis and the functional importance of neurogenesis in antidepressant efficacy.

(a) Animal models of depression

\begin{tabular}{|c|c|c|c|c|c|c|}
\hline Reference & Species & Sex & Model & Antidepressant & $\begin{array}{c}\text { Method of } \\
\text { ablation }\end{array}$ & Summary of findings \\
\hline $\begin{array}{l}\text { Snyder et al. } \\
2011[96]\end{array}$ & Mouse & M & Restraint & - & $\begin{array}{c}\text { X-ray; } \\
\text { transgenic }\end{array}$ & $\begin{array}{l}\text { Neurogenesis-dependent regulation of HPA } \\
\text { response to stress and behavioural measures (NSF, } \\
\text { FST, and SC) }\end{array}$ \\
\hline $\begin{array}{l}\text { David et al. } \\
2009[64]\end{array}$ & Mouse & $\mathrm{M}$ and $\mathrm{F}$ & $\begin{array}{l}\text { Chronic } \\
\text { corticosterone } \\
\text { administration }\end{array}$ & Fluoxetine & $\mathrm{X}$-ray & $\begin{array}{l}\text { Neurogenesis-dependent (NSF) and -independent } \\
\text { (OFT, FST) aspects of antidepressant efficacy }\end{array}$ \\
\hline $\begin{array}{l}\text { Bessa et al. } \\
2009 \text { [65] }\end{array}$ & Rat & M & $\begin{array}{l}\text { Chronic mild } \\
\text { stress }\end{array}$ & $\begin{array}{l}\text { Imipramine; } \\
\text { fluoxetine }\end{array}$ & MAM & $\begin{array}{l}\text { Neurogenesis-dependent (NSF) and -independent } \\
\text { (SC, FST) aspects of antidepressant efficacy. } \\
\text { Significant alterations in neural plasticity } \\
\text { associated with antidepressant efficacy }\end{array}$ \\
\hline $\begin{array}{l}\text { Surget et al. } \\
2008 \text { [92] }\end{array}$ & Mouse & M & $\begin{array}{l}\text { Chronic } \\
\text { unpredictable } \\
\text { stress }\end{array}$ & $\begin{array}{l}\text { Imipramine; } \\
\text { fluoxetine }\end{array}$ & & $\begin{array}{l}\text { Neurogenesis-dependent (NSF, CS, ST) and } \\
\text {-independent (A) aspects of antidepressant } \\
\text { efficacy }\end{array}$ \\
\hline $\begin{array}{l}\text { Holick et al. } \\
2008 \text { [93] }\end{array}$ & Mouse & M & - & Fluoxetine & X-ray & $\begin{array}{l}\text { Neurogenesis-independent effects of } \\
\text { antidepressant efficacy }\end{array}$ \\
\hline $\begin{array}{l}\text { Airan et al. } \\
2007[94]\end{array}$ & Rat & F & $\begin{array}{l}\text { Chronic mild } \\
\text { stress }\end{array}$ & $\begin{array}{l}\text { Imipramine; } \\
\text { fluoxetine }\end{array}$ & X-ray & $\begin{array}{l}\text { Neurogenesis-dependent (NSF) and -independent } \\
\text { (OFT) aspects of antidepressant efficacy }\end{array}$ \\
\hline $\begin{array}{l}\text { Alonso et al. } \\
2004[85]\end{array}$ & Mouse & M & $\begin{array}{l}\text { Chronic mild } \\
\text { stress }\end{array}$ & Fluoxetine & - & $\begin{array}{l}\text { Decreased cell proliferation in the DG, while } \\
\text { chronic fluoxetine blocked this effect }\end{array}$ \\
\hline $\begin{array}{l}\text { Santarelli et } \\
\text { al. } 2003[21]\end{array}$ & Mouse & M & - & $\begin{array}{l}\text { Imipramine; } \\
\text { fluoxetine }\end{array}$ & X-ray & $\begin{array}{l}\text { Neurogenesis-dependent (NSF) antidepressant } \\
\text { efficacy }\end{array}$ \\
\hline $\begin{array}{l}\text { Czéh et al. } \\
2002[78]\end{array}$ & Rat & M & $\begin{array}{c}\text { Social } \\
\text { subordination }\end{array}$ & - & - & $\begin{array}{l}\text { Decreased cell proliferation and survival in the } \\
\text { DG }\end{array}$ \\
\hline $\begin{array}{l}\text { Malberg et al. } \\
2000[9]\end{array}$ & Rat & M & - & $\begin{array}{l}\text { Fluoxetine; } \\
\text { reboxetine; } \\
\text { tranylcypromine; } \\
\text { ECS } \\
\end{array}$ & - & $\begin{array}{l}\text { Chronic, but not acute, treatment with } \\
\text { monoaminergic antidepressant and ECS } \\
\text { increased cell proliferation in the DG }\end{array}$ \\
\hline
\end{tabular}

(b) Human studies of depression

\begin{tabular}{|c|c|c|c|c|c|}
\hline Reference & Subjects & Sex & $\begin{array}{l}\text { Population } \\
\text { assessed }\end{array}$ & Antidepressant & Effect on neurogenesis \\
\hline $\begin{array}{l}\text { Cobb et al. } 2013 \\
{[74]}\end{array}$ & Humans & $\mathrm{M}$ and $\mathrm{F}$ & $\begin{array}{l}\text { Depressed patients } \\
\text { postmortem }\end{array}$ & - & $\begin{array}{l}\text { No significant difference in number of granule cells } \\
\text { between depressed subjects and controls; decreased } \\
\text { hippocampal volume correlating with duration of } \\
\text { disease }\end{array}$ \\
\hline $\begin{array}{l}\text { Boldrini et al. } \\
2013 \text { [75] }\end{array}$ & Humans & $\mathrm{M}$ and $\mathrm{F}$ & $\begin{array}{l}\text { Depressed patients } \\
\text { postmortem }\end{array}$ & SSRIs; TCAs & $\begin{array}{l}\text { Depression is associated with a decreased number of } \\
\text { granule neurons, correlated with reduced DG } \\
\text { volume. SSRI and TCA treatment increase granule } \\
\text { neuron number and DG volume }\end{array}$ \\
\hline $\begin{array}{l}\text { Boldrini et al. } \\
2012[22]\end{array}$ & Humans & $\mathrm{M}$ and $\mathrm{F}$ & $\begin{array}{l}\text { Depressed patients } \\
\text { postmortem }\end{array}$ & SSRIs; TCAs & $\begin{array}{l}\text { Both antidepressant classes increase cell proliferation } \\
\text { over untreated depressed patients and controls; } \\
\text { NPCs associated with angiogenesis }\end{array}$ \\
\hline $\begin{array}{l}\text { Boldrini et al. } \\
2009 \text { [23] }\end{array}$ & Humans & $\mathrm{M}$ and $\mathrm{F}$ & $\begin{array}{l}\text { Depressed patients } \\
\text { postmortem }\end{array}$ & SSRIs; TCAs & $\begin{array}{l}\text { Both antidepressant classes increase cell proliferation } \\
\text { over untreated depressed patients and controls }\end{array}$ \\
\hline $\begin{array}{l}\text { Stockmeier et al. } \\
2004[76]\end{array}$ & Humans & $\mathrm{M}$ and $\mathrm{F}$ & $\begin{array}{l}\text { Depressed patients } \\
\text { postmortem }\end{array}$ & - & $\begin{array}{l}\text { Increased density of granule cells in the DG of } \\
\text { depressed subjects compared to controls }\end{array}$ \\
\hline
\end{tabular}

NSF: novelty suppressed feeding; FST: forced swim test; SC: sucrose consumption; OFT: open field test; CS: coat state; ST: splash test; A: actimeter; MAM: methylazoxymethanol acetate (cytostatic agent).

LTD [35], where the polysialylation of NCAM is positively correlated with neural activity of glutamatergic neurons $[120,121]$. Moreover, inhibiting the polysialylation of NCAM reduces the rate of dendritic spine formation and decreases the stability of these spines [122]. Interestingly PSA-NCAM is also directly related to monoaminergic neurotransmission, as PSA-NCAM expression is directly modulated by the 5HT1A receptor [123]. Moreover, serotonergic innervation plays a role in regulating the expression of PSA-NCAM in the hippocampus [124]. Given the interaction of serotonergic 
TABLE 2: Selected publications delineating the role of PSA-NCAM in adult hippocampal neurogenesis.

\begin{tabular}{|c|c|c|c|c|}
\hline Authors & Species & $\begin{array}{c}\text { Role in } \\
\text { neurogenesis }\end{array}$ & $\begin{array}{c}\text { Ablation } \\
\text { method }\end{array}$ & Findings \\
\hline McCall et al. 2013 [97] & Rat & $\begin{array}{l}\text { Neurite outgrowth; } \\
\text { survival }\end{array}$ & EndoN & $\begin{array}{l}\text { Cleavage of PSA-NCAM caused expanded dendritic arborization } \\
\text { and increased cell death }\end{array}$ \\
\hline Burgess et al. 2008 [10] & Rat & $\begin{array}{l}\text { Migration; } \\
\text { differentiation }\end{array}$ & EndoN & $\begin{array}{l}\text { Cleavage of PSA-NCAM disrupts normal migration and } \\
\text { differentiation of newly generated neurons in the DG }\end{array}$ \\
\hline Seri et al. 2004 [99] & $?$ & Differentiation & - & $\begin{array}{l}\text { PSA-NCAM is highly expressed in the entire cell body and } \\
\text { growing processes of D cells (precursors in the generation of new } \\
\text { granule neurons in the dentate gyrus) }\end{array}$ \\
\hline $\begin{array}{l}\text { Ni Dhuill et al. } 1999 \\
\text { [100] }\end{array}$ & Human & $\begin{array}{l}\text { Proliferation; } \\
\text { neurite outgrowth }\end{array}$ & - & $\begin{array}{l}\text { Hippocampal expression of PSA-NCAM throughout life in } \\
\text { humans closely resembles that of the rat. Expression largely } \\
\text { contained to granule cells of the dentate gyrus and their mossy } \\
\text { fiber axons, with large reductions in expression with age }\end{array}$ \\
\hline $\begin{array}{l}\text { Seki and Rutishauser } \\
1998[98]\end{array}$ & Mouse & Neurite outgrowth & $\begin{array}{l}\text { NCAM KO; } \\
\text { EndoN }\end{array}$ & $\begin{array}{l}\text { Aberrant collateral sprouting of mossy fibers and ectopic synaptic } \\
\text { bouton formation }\end{array}$ \\
\hline Kuhn et al. 1996 [101] & Rat & Migration & - & $\begin{array}{l}\text { Age related decline in PSA-NCAM expression in the GCL, } \\
\text { reduced migration of PSA-NCAM expressing cells into the GCL }\end{array}$ \\
\hline Fox et al. 1995 [102] & Rat & Proliferation & - & $\begin{array}{l}\text { PSA-NCAM expression decreases with age, coinciding with } \\
\text { decreased cell proliferation }\end{array}$ \\
\hline Seki and Arai 1993 [103] & Rat & $\begin{array}{l}\text { Proliferation; } \\
\text { migration; } \\
\text { differentiation }\end{array}$ & - & $\begin{array}{l}\text { Newly generated granule cells in the dentate gyrus express a } \\
\text { highly polysialylated form of NCAM, involved in the migration } \\
\text { of immature neurons from the subgranular zone into the GCL }\end{array}$ \\
\hline Seki and Arai 1991 [104] & Rat & Proliferation & - & $\begin{array}{l}\text { Highly polysialylated form of NCAM is persistently expressed in } \\
\text { the adult dentate gyrus }\end{array}$ \\
\hline
\end{tabular}

EndoN: endoneuraminidase N; GCL: granule cell layer.

neurotransmission with PSA-NCAM and its putative role in regulating synaptic plasticity, it is possible that PSA-NCAM may mediate some of the effects of antidepressant treatment on monoaminergic tone.

The ability of PSA-NCAM to directly alter hippocampal neurogenesis is evidenced by the selective removal of the PSA moiety from NCAM with the bacteriophage enzyme EndoN. Application of EndoN disrupts normal migration of newly produced cells and alters differentiation of these new cells by shifting them toward a neuronal phenotype [10]. Selective cleavage of PSA also produces enhanced dendritic arborization, aberrant mossy fiber sprouting, produces ectopic synaptic bouton formation, and increases cell death within the hippocampus $[97,98]$.

Given the role of PSA-NCAM in mediating multiple aspects of neural plasticity it appears to function at the confluence of the prevailing theories of depression: monoaminergic, neurotrophic, and neurogenic, thus making it an interesting target for future study. Further research is necessary to elucidate the role of PSA-NCAM and similar proteins, in the etiology of depression and efficacy of antidepressant drugs.

\section{Role of Neurotrophic Factors in Antidepressant Efficacy}

Brain-derived neurotrophic factor (BDNF) has been implicated in the etiology and treatment of depression. Depressed patients show decreased levels of serum BDNF $[125,126]$, which is correlated with decreased hippocampal volume and increased ratings of depression [126]. Conversely, increased
BDNF levels are associated with antidepressant treatment and alleviation of depression [127]. These findings are mirrored in rodent models of depression [128-132] as chronic antidepressant treatment increases BDNF levels, coinciding with alleviation of depressive-like behaviours [130-132], and intracranial infusion of BDNF produces antidepressant effects $[128,133]$.

Activation of the TrkB neurotrophin receptor largely mediates the plasticity-enhancing actions of BDNF [134136], where inhibition of $\operatorname{TrkB}$ signalling attenuates the behavioural efficacy of antidepressants [136]. Conversely BDNF, or more specifically proBDNF, via activation of the p75 neurotrophin receptor mediates plasticity-reducing actions such as apoptosis, neural atrophy, and synaptic pruning [137]. It has been postulated that the balance of TrkB and p75 signalling may underlie antidepressant effects of BDNF, suggesting a mechanism through which stress/depression may modulate the effects of BDNF. To this point, knocking out $\operatorname{TrkB}$ receptors fails to produce a depressive-like phenotype in neurogenesis-dependent or -independent behavioural measures of antidepressant efficacy $[138,139]$; however sex differences exist as female TrkB knockouts do appear to develop a depressive-like behavioural phenotype [140].

Interestingly, PSA-NCAM interacts with BDNF, as removal of PSA from NCAM inhibits the induction of LTP, and the application of exogenous BDNF restores LTP at the affected synapse [141]. Further, disruption of the polysialylation of NCAM also disturbs the effects of BDNF on cortical neuron differentiation and survival, while the application of exogenous BDNF reverses these effects [142]. 
TABLE 3: Effects of stress and depression on the expression of PSA-NCAM.

(a) Animal models of stress and depression

\begin{tabular}{|c|c|c|c|c|c|}
\hline Reference & Species & Sex & Model & Antidepressant & Effect on PSA-NCAM \\
\hline Gilabert-Juan et al. 2012 [110] & Mouse & M & Chronic restraint stress & - & $\leftrightarrow$ in $\mathrm{mPFC}$ \\
\hline Djordjevic et al. 2012 [111] & Rat & M & Chronic social isolation & - & $\uparrow$ in $\mathrm{HPC} ; \downarrow$ PFC \\
\hline Djordjevic et al. 2012 [109] & Rat & M & Chronic social isolation & Fluoxetine & $\uparrow$ in HPC, $\downarrow$ by Flx treatment \\
\hline Djordjevic et al. 2012 [112] & Rat & M & Chronic social isolation & Fluoxetine & $\uparrow$ in PFC; $\downarrow$ by Flx treatment (with stress) \\
\hline Gilabert-Juan et al. 2011 [113] & Mouse & M & Chronic restraint stress & - & $\downarrow$ in $\mathrm{CeM} ; \leftrightarrow$ in $\mathrm{BLA} ; \leftrightarrow \mathrm{Me}$ \\
\hline Wainwright et al. 2011 [11] & Rat & M & $\begin{array}{l}\text { Unpredictable chronic } \\
\text { mild stress }\end{array}$ & - & $\downarrow$ in HPC \\
\hline Homberg et al. 2011 [116] & Rat & M & - & Fluoxetine & $\begin{array}{l}\downarrow \text { in } \mathrm{dRN} ; \leftrightarrow \text { in } \mathrm{mPFC} ; \uparrow \text { AMYG } \\
\text { (adolescent), } \downarrow \text { AMYG (adult) }\end{array}$ \\
\hline Varea et al. 2007 [117] & Rat & M & - & Fluoxetine & $\begin{array}{c}\uparrow \text { in HPC (str. luc. only); } \downarrow \text { in Me and } \\
\text { BMA; } \leftrightarrow \text { in BLA }\end{array}$ \\
\hline Sairanen et al. 2007 [118] & Rat & M & - & Imipramine & $\uparrow$ in $\mathrm{HPC} ; \uparrow$ plPFC \\
\hline Varea et al. 2007 [119] & Rat & M & - & Fluoxetine & $\uparrow$ in mPFC (whole); $\uparrow$ ilPFC; $\leftrightarrow$ plPFC \\
\hline Cordero et al. 2005 [105] & Rat & M & Chronic restraint stress & - & $\downarrow$ in $\mathrm{CeM} ; \downarrow$ Me \\
\hline Nacher et al. 2004 [66] & Rat & M & $\begin{array}{l}\text { Oral corticosterone } \\
\text { administration }\end{array}$ & - & $\downarrow$ in $\mathrm{HPC}$ \\
\hline Nacher et al. 2004 [106] & Rat & M & $\begin{array}{l}\text { Chronic restraint stress; } \\
\text { oral corticosterone } \\
\text { administration }\end{array}$ & - & $\begin{array}{l}\downarrow \text { in piriform cortex (oral CORT); } \uparrow \text { in } \\
\text { piriform cortex (restraint) }\end{array}$ \\
\hline Pham et al. 2003 [107] & Rat & M & Chronic restraint stress & - & $\uparrow$ in HPC ( 3 weeks), $\leftrightarrow$ in HPC ( 6 weeks) \\
\hline Sandi et al. 2001 [108] & Rat & M & Chronic restraint stress & - & $\uparrow$ in HPC \\
\hline
\end{tabular}

(b) Human studies of depression

\begin{tabular}{lccccc}
\hline Reference & Subjects & Sex & Population assessed & Antidepressant & Effect on PSA-NCAM \\
\hline $\begin{array}{l}\text { Maheu et al. 2013 [114] } \\
\text { Gilabert-Juan et al. 2012 }\end{array}$ & Human & ? & $\begin{array}{c}\text { Depressed patients } \\
\text { postmortem } \\
\text { [115] }\end{array}$ & $\begin{array}{c}\text { Specific classes not } \\
\text { disclosed }\end{array}$ & $\begin{array}{c}\text { Depressed patients } \\
\text { postmortem } \\
\text { Varea et al. 2012 [2] }\end{array}$ \\
\hline
\end{tabular}

Me: medial amygdala; CeM: centromedial amygdala; BMA: basomedial amygdala; dRN: dorsal raphe nucleus; str. luc.: stratum lucidum; plPFC: prelimbic cortex; ilPFC: infralimbic prefrontal cortex; HPC: hippocampus; AMYG: amygdala; mPFC: medial prefrontal cortex.

These findings suggest that PSA-NCAM may mediate the responsiveness of neurons to BDNF. It is known that PSANCAM interacts with, and may regulate, p75 expression in septal neurons [143] and newly generated neurons of the SVZ [144]. Indeed knockout of p75 significantly reduces the expression of PSA-NCAM in SVZ neuroblasts [145]. As previously mentioned the p75 receptor is involved in the regulation of adult hippocampal neurogenesis [146] and regulates neurogenesis stimulated by chronic antidepressant treatment [147]. Given the complex and varied role of BDNF in the etiology of depression and antidepressant treatment more research is needed to further elucidate a mechanism through which the modulation of BDNF exerts its influence.

\section{Gonadal Hormones, Depression, and Modulation of Neural Plasticity}

Women are twice as likely as men to develop depression [148]. Sex differences are also seen in antidepressant efficacy as men have a better response to TCAs, while women have a better response to SSRIs [149], although these findings remain controversial. Any sex difference observed suggests that gonadal hormone levels are involved, and indeed there is evidence that androgens may protect males from the development of depression. Interestingly, there is an increased incidence of depression in males coinciding with the age related decline in testosterone levels [150-153]. Similarly, young hypogonadal males are more susceptible to developing depression [154], portending protective effects of testosterone against the development of depression. Testosterone has shown some antidepressant action as testosterone replacement therapies are efficacious in alleviating depressive symptoms in hypogonadal men $[152,155,156]$. Testosterone replacement also has efficacy as an adjunct treatment to clinical antidepressants in cases of treatment-resistant depression [155, 157]; however it should be noted that androgen therapies are not always seen to be effective for men suffering depression $[158,159]$.

Gonadal hormones in females are also likely a factor in the treatment and etiology of depression. Times of dramatic hormone fluctuation, such as during the postpartum and 
perimenopause, are associated with an increased incidence in depression [160, 161]. In addition hormonal replacement can show antidepressant effects during the postpartum and in peri- and postmenopausal women [162-164]. Consistent with clinical studies, gonadal hormones are also effective as an adjunct therapy to chronic antidepressant treatment in animal models. For example, chronic imipramine increases hippocampal neurogenesis in intact but not in ovariectomized rats [165]. Another study found that an SSRI decreased immobility in the FST in ovariectomized female rats, but only with adjunct estradiol treatment [166]. Similarly, testosterone potentiates the effects of imipramine in increasing cell proliferation and facilitates the alleviation of depressive-like behavioural phenotypes in castrated socially isolated male rats [167]. Consequently androgens and estrogens may have antidepressant properties which could impede the development of, or ameliorate, extant depressive disorders.

Interestingly gonadal hormones modulate adult neurogenesis, BDNF levels, and PSA-NCAM expression in the hippocampus. Testosterone and its metabolite dihydrotestosterone (DHT) both serve to enhance hippocampal neurogenesis through improved cell survival via an androgendependent mechanism within the dentate gyrus [168]. Similarly, estrogens are able to increase adult neurogenesis via proliferation or survival depending on duration of treatment [169]. Estrogens regulate the polysialylation of NCAM across the estrous cycle [170], while the removal of testicular hormones decreases PSA-NCAM expression in the dentate gyrus [11]. Significant interplay exists between gonadal hormones and BDNF, as testosterone and DHT interact with BDNF to modulate synaptic plasticity, dendritic morphology, and neurogenesis in the central nervous system [171-174]. Estrogens and BDNF also share widespread interactions, as estradiol regulates hippocampal BDNF $[175,176]$ levels possibly through an estrogen-sensitive response element on the BDNF gene [177]. Conversely, BDNF mediates estradiolinduced alterations in hippocampal dendritic spine density [178]. Thus gonadal hormones may play a role in facilitating antidepressant efficacy through the modulation of neural plasticity.

\section{Effects of Experimental Manipulation on Neural Plasticity}

Many of the studies examining a reduction in neurogenesis have used viral vectors, irradiation, or the cytostatic agent, methylazoxymethanol. It is important to note that the experimental manipulation of neurogenesis also likely produces downstream effects on neural plasticity in a much broader sense, including the expression of cell adhesion molecules (including PSA-NCAM), synaptic proteins, and BDNF. As such, it is difficult to know for sure whether the attenuation of antidepressant efficacy via reductions in neurogenesis is due to changes in neurogenesis levels or other aspects of neural plasticity. For instance, radiation levels as low as $2.5 \mathrm{~Gy}$ significantly reduce the density of BDNF-expressing neurons [179] and the expression of PSA-NCAM in the hippocampus [180]. This is important as a 10 Gy dose of radiation is typically used to inhibit neurogenesis in studies assessing attenuated neurogenesis $[21,96,181]$, suggesting BDNF and PSA-NCAM expression will also be affected. This suggests that the effects of radiation affect proteins associated with neural remodelling and synaptic plasticity as well as neurogenesis [180]. It is important to address these caveats in future research to further elucidate the role of neurogenesis and neural plasticity in depression and its treatment.

\section{Conclusion}

Depression is a complex neuropsychiatric disease with a poorly defined etiology. While hosts of antidepressant drugs do exist, they are often inefficacious. Elucidating the neural underpinnings of depression and fully understanding the pleiotropic effects of current antidepressant compounds, beyond their role in modulating monoaminergic neurotransmission, are necessary for the development of more effective drugs. The potential role of neurogenesis, both its decline with the occurrence of depression and its enhancement by chronic treatment with antidepressant drugs and therapies, has provided a promising avenue for research. Though significant findings have been made relating neurogenesis to the effective treatment of depression, large gaps in our understanding still exist. To this end, the role of synaptic proteins and cell adhesion molecules, including PSA-NCAM, in the etiology and treatment of depression should also be investigated. As with neurogenesis, PSA-NCAM is reduced in depressed patients and in models of depression, while chronic antidepressant treatment increases expression of PSA-NCAM. Importantly however, PSA-NCAM mediates multiple facets of neural plasticity, including neurogenesis and synaptic plasticity, in addition to mediating effects of neurotrophic factors, such as BDNF. PSA-NCAM therefore functions at the confluence of many forms of neural plasticity, and its mechanisms bridge several theories of depression: monoamine, neurogenic, and neurotrophic. This review has focused on the potential roles of neurogenesis and PSANCAM in depression; however many other proteins are associated with neural plasticity and depression [29, 182, 183]. Given the limitations in the understanding of the genesis of depression and current antidepressant treatments, continued research into the exact contribution of adult neurogenesis and the potential roles of proteins associated with neural plasticity and the continued perusal of a broader, neural plasticity hypothesis of depression are certainly warranted.

\section{Acknowledgment}

Liisa A. M. Galea was funded for this research by a grant from the Coast Capital Depression Fund.

\section{References}

[1] L. Wilbrecht, A. Holtmaat, N. Wright, K. Fox, and K. Svoboda, "Structural plasticity underlies experience-dependent functional plasticity of cortical circuits," Journal of Neuroscience, vol. 30, no. 14, pp. 4927-4932, 2010.

[2] E. Varea, R. Guirado, J. Gilabert-Juan et al., "Expression of PSANCAM and synaptic proteins in the amygdala of psychiatric disorder patients," Journal of Psychiatric Research, vol. 46, no. 2, pp. 189-197, 2012. 
[3] S. T. DeKosky and S. W. Scheff, "Synapse loss in frontal cortex biopsies in Alzheimer's disease: correlation with cognitive severity," Annals of Neurology, vol. 27, no. 5, pp. 457-464, 1990.

[4] P. Calabresi, N. B. Mercuri, and M. Di Filippo, "Synaptic plasticity, dopamine and Parkinson's disease: one step ahead," Brain, vol. 132, no. 2, pp. 285-287, 2009.

[5] D. A. Lewis and G. González-Burgos, "Neuroplasticity of neocortical circuits in schizophrenia," Neuropsychopharmacology, vol. 33, no. 1, pp. 141-165, 2008.

[6] J. Altman, "Are new neurons formed in the brains of adult mammals?" Science, vol. 135, no. 3509, pp. 1127-1128, 1962.

[7] P. S. Eriksson, E. Perfilieva, T. Björk-Eriksson et al., "Neurogenesis in the adult human hippocampus," Nature Medicine, vol. 4, no. 11, pp. 1313-1317, 1998.

[8] M. S. Kaplan and J. W. Hinds, "Neurogenesis in the adult rat: electron microscopic analysis of light radioautographs," Science, vol. 197, no. 4308, pp. 1092-1094, 1977.

[9] J. E. Malberg, A. J. Eisch, E. J. Nestler, and R. S. Duman, "Chronic antidepressant treatment increases neurogenesis in adult rat hippocampus," Journal of Neuroscience, vol. 20, no. 24, pp. 9104-9110, 2000.

[10] A. Burgess, S. R. Wainwright, L. S. Shihabuddin, U. Rutishauser, T. Seki, and I. Aubert, "Polysialic acid regulates the clustering, migration, and neuronal differentiation of progenitor cells in the adult hippocampus," Developmental Neurobiology, vol. 68, no. 14, pp. 1580-1590, 2008.

[11] S. R. Wainwright, S. E. Lieblich, and L. A. Galea, "Hypogonadism predisposes males to the development of behavioural and neuroplastic depressive phenotypes," Psychoneuroendocrinology, vol. 36, no. 9, pp. 1327-1341, 2011.

[12] G. Kempermann, H. G. Kuhn, and F. H. Gage, "Experienceinduced neurogenesis in the senescent dentate gyrus," Journal of Neuroscience, vol. 18, no. 9, pp. 3206-3212, 1998.

[13] J. M. Barker and L. A. M. Galea, "Repeated estradiol administration alters different aspects of neurogenesis and cell death in the hippocampus of female, but not male, rats," Neuroscience, vol. 152, no. 4, pp. 888-902, 2008.

[14] H. van Praag, G. Kempermann, and F. H. Gage, "Running increases cell proliferation and neurogenesis in the adult mouse dentate gyrus," Nature Neuroscience, vol. 2, no. 3, pp. 266-270, 1999.

[15] G. Kempermann, "Why new neurons? Possible functions for adult hippocampal neurogenesis," Journal of Neuroscience, vol. 22, no. 3, pp. 635-638, 2002.

[16] R. S. Duman, J. Malberg, and S. Nakagawa, "Regulation of adult neurogenesis by psychotropic drugs and stress," Journal of Pharmacology and Experimental Therapeutics, vol. 299, no. 2, pp. 401-407, 2001.

[17] J. R. Epp, M. D. Spritzer, and L. A. M. Galea, "Hippocampusdependent learning promotes survival of new neurons in the dentate gyrus at a specific time during cell maturation," Neuroscience, vol. 149, no. 2, pp. 273-285, 2007.

[18] J. S. Snyder, N. S. Hong, R. J. McDonald, and J. M. Wojtowicz, "A role for adult neurogenesis in spatial long-term memory," Neuroscience, vol. 130, no. 4, pp. 843-852, 2005.

[19] E. Gould, A. Beylin, P. Tanapat, A. Reeves, and T. J. Shors, "Learning enhances adult neurogenesis in the hippocampal formation," Nature Neuroscience, vol. 2, no. 3, pp. 260-265, 1999.

[20] T. J. Shors, G. Miesegaes, A. Beylin, M. Zhao, T. Rydel, and E. Gould, "Neurogenesis in the adult is involved in the formation of trace memories," Nature, vol. 410, no. 6826, pp. 372-376, 2001.
[21] L. Santarelli, M. Saxe, C. Gross et al., "Requirement of hippocampal neurogenesis for the behavioral effects of antidepressants," Science, vol. 301, no. 5634, pp. 805-809, 2003.

[22] M. Boldrini, R. Hen, M. D. Underwood et al., "Hippocampal angiogenesis and progenitor cell proliferation are increased with antidepressant use in major depression," Biological Psychiatry, vol. 72, no. 7, pp. 562-571, 2012.

[23] M. Boldrini, M. D. Underwood, R. Hen et al., "Antidepressants increase neural progenitor cells in the human hippocampus," Neuropsychopharmacology, vol. 34, no. 11, pp. 2376-2389, 2009.

[24] M. S. Fanselow and H. W. Dong, "Are the dorsal and ventral hippocampus functionally distinct structures?" Neuron, vol. 65, no. 1, pp. 7-19, 2010.

[25] D. M. Bannerman, J. N. Rawlins, S. B. McHugh et al., "Regional dissociations within the hippocampus-memory and anxiety," Neuroscience \& Biobehavioral Reviews, vol. 28, no. 3, pp. 273283, 2004.

[26] A. Gärtner and D. Frantz, Hippocampus: Anatomy, Functions and Neurobiology. Neuroanatomy Research at the Leading Edge Series, vol. 11, Nova Science, New York, NY, USA, 2010.

[27] M. Koehl and D. N. Abrous, "A new chapter in the field of memory: adult hippocampal neurogenesis," European Journal of Neuroscience, vol. 33, no. 6, pp. 1101-1114, 2011.

[28] M. B. Dalva, A. C. McClelland, and M. S. Kayser, "Cell adhesion molecules: signalling functions at the synapse," Nature Reviews Neuroscience, vol. 8, no. 3, pp. 206-220, 2007.

[29] C. Sandi, "Stress, cognitive impairment and cell adhesion molecules," Nature Reviews Neuroscience, vol. 5, no. 12, pp. 917930, 2004.

[30] L. Bonfanti, "PSA-NCAM in mammalian structural plasticity and neurogenesis," Progress in Neurobiology, vol. 80, no. 3, pp. 129-164, 2006.

[31] L. Bonfanti and D. T. Theodosis, "Polysialic acid and activitydependent synapse remodeling," Cell Adhesion and Migration, vol. 3, no. 1, pp. 43-50, 2009.

[32] O. Senkov, O. Tikhobrazova, and A. Dityatev, "PSA-NCAM: synaptic functions mediated by its interactions with proteoglycans and glutamate receptors," The International Journal of Biochemistry \& Cell Biology, vol. 44, no. 4, pp. 591-595, 2012.

[33] J. Finne, U. Finne, H. Deagostini-Bazin, and C. Goridis, "Occurrence of $\alpha 2-8$ linked polysialosyl units in a neural cell adhesion molecule," Biochemical and Biophysical Research Communications, vol. 112, no. 2, pp. 482-487, 1983.

[34] E. Gascon, L. Vutskits, and J. Z. Kiss, "Polysialic acid-neural cell adhesion molecule in brain plasticity: from synapses to integration of new neurons," Brain Research Reviews, vol. 56, no. 1, pp. 101-118, 2007.

[35] D. Muller, C. Wang, G. Skibo et al., "PSA-NCAM is required for activity-induced synaptic plasticity," Neuron, vol. 17, no. 3, pp. 413-422, 1996.

[36] U. Rutishauser, M. Watanabe, and J. Silver, "Specific alteration of NCAM-mediated cell adhesion by an endoneuraminidase," Journal of Cell Biology, vol. 101, no. 5, pp. 1842-1849, 1985.

[37] T. B. Ustun, J. L. Ayuso-Mateos, S. Chatterji, C. Mathers, and C. J. L. Murray, "Global burden of depressive disorders in the year 2000," The British Journal of Psychiatry, vol. 184, pp. 386-392, 2004.

[38] P. E. Greenberg and H. G. Birnbaum, "The economic burden of depression in the US: societal and patient perspectives," Expert Opinion on Pharmacotherapy, vol. 6, no. 3, pp. 369-376, 2005. 
[39] American Psychiatric Association, Diagnostic Criteria From DSM-IV-TR, vol. 12, American Psychiatric Association, Washington, DC, USA, 2000.

[40] S. E. Byrne and A. J. Rothschild, "Loss of antidepressant efficacy during maintenance therapy: possible mechanisms and treatments," Journal of Clinical Psychiatry, vol. 59, no. 6, pp. 279-288, 1998.

[41] M. H. Trivedi, A. J. Rush, S. R. Wisniewski et al., "Evaluation of outcomes with citalopram for depression using measurementbased care in STAR $* \mathrm{D}$ : implications for clinical practice," American Journal of Psychiatry, vol. 163, no. 1, pp. 28-40, 2006.

[42] G. Piñeyro and P. Blier, "Autoregulation of serotonin neurons: role in antidepressant drug action," Pharmacological Reviews, vol. 51, no. 3, pp. 533-591, 1999.

[43] G. E. Crane, "Iproniazid (marsilid) phosphate, a therapeutic agent for mental disorders and debilitating diseases," Psychiatric Research Reports, vol. 8, pp. 142-152, 1957.

[44] I. J. Selikoff, E. H. Robitzek, and G. G. Ornstein, “Treatment of pulmonary tuberculosis with hydrazide derivatives of isonicotinic acid," Journal of the American Medical Association, vol. 150, no. 10, pp. 973-980, 1952.

[45] R. KUHN, "The treatment of depressive states with G 22355 (imipramine hydrochloride)," The American Journal of Psychiatry, vol. 115, no. 5, pp. 459-464, 1958.

[46] P. Fangmann, H. J. Assion, G. Juckel, C. Á. González, and F. López-Muñoz, "Half a century of antidepressant drugs: on the clinical introduction of monoamine oxidase inhibitors, tricyclics, and tetracyclics. Part II: tricyclics and tetracyclics," Journal of Clinical Psychopharmacology, vol. 28, no. 1, pp. 1-4, 2008.

[47] F. López-Muñoz, C. Álamo, G. Juckel, and H. J. Assion, "Half a century of antidepressant drugs: on the clinical introduction of monoamine oxidase inhibitors, tricyclics, and tetracyclics. Part I: monoamine oxidase inhibitors," Journal of Clinical Psychopharmacology, vol. 27, no. 6, pp. 555-559, 2007.

[48] R. M. A. Hirschfeld, "History and evolution of the monoamine hypothesis of depression," Journal of Clinical Psychiatry, vol. 61, supplement 6, pp. 4-6, 2000.

[49] M. E. Thase, M. H. Trivedi, and A. J. Rush, "MAOIs in the contemporary treatment of depression," Neuropsychopharmacology, vol. 12, no. 3, pp. 185-219, 1995.

[50] M. E. Thase, "Effectiveness of antidepressants: comparative remission rates," Journal of Clinical Psychiatry, vol. 64, supplement 2, pp. 3-7, 2003.

[51] F. M. Quitkin, J. D. Rabkin, and J. M. Markowitz, "Use of pattern analysis to identify true drug response: a replication," Archives of General Psychiatry, vol. 44, no. 3, pp. 259-264, 1987.

[52] I. M. Anderson, D. J. Nutt, and J. F. W. Deakin, "Evidencebased guidelines for treating depressive disorders with antidepressants: a revision of the 1993 British Association for Psychopharmacology guidelines," Journal of Psychopharmacology, vol. 14, no. 1, pp. 3-20, 2000.

[53] P. Blier, "The pharmacology of putative early-onset antidepressant strategies," European Neuropsychopharmacology, vol. 13, no. 2, pp. 57-66, 2003.

[54] F. M. Quitkin, J. G. Rabkin, and D. Ross, "Identification of true drug response to antidepressants. Use of pattern analysis," Archives of General Psychiatry, vol. 41, no. 8, pp. 782-786, 1984.

[55] P. Blier, C. De Montigny, and Y. Chaput, "Modifications of the serotonin system by antidepressant treatments: implications for the therapeutic response in major depression," Journal of Clinical Psychopharmacology, vol. 7, supplement 6, pp. 24S-35S, 1987.
[56] S. Stahl, "Is serotonin receptor down-regulation linked to the mechanism of action of antidepressant drugs?" Psychopharmacology Bulletin, vol. 30, no. 1, pp. 39-43, 1994.

[57] C. K. J. Lieben, H. W. M. Steinbusch, and A. Blokland, “5,7-DHT lesion of the dorsal raphe nuclei impairs object recognition but not affective behavior and corticosterone response to stressor in the rat," Behavioural Brain Research, vol. 168, no. 2, pp. 197-207, 2006.

[58] B. L. Jacobs, H. Van Praag, and F. H. Gage, "Adult brain neurogenesis and psychiatry: a novel theory of depression," Molecular Psychiatry, vol. 5, no. 3, pp. 262-269, 2000.

[59] C. Schüle, "Neuroendocrinological mechanisms of actions of antidepressant drugs," Journal of Neuroendocrinology, vol. 19, no. 3, pp. 213-226, 2007.

[60] K. J. Parker, A. F. Schatzberg, and D. M. Lyons, "Neuroendocrine aspects of hypercortisolism in major depression," Hormones and Behavior, vol. 43, no. 1, pp. 60-66, 2003.

[61] M. Ising, S. Horstmann, S. Kloiber et al., "Combined dexamethasone/corticotropin releasing hormone test predicts treatment response in major depression-a potential biomarker?" Biological Psychiatry, vol. 62, no. 1, pp. 47-54, 2007.

[62] M. E. Keck, "Corticotropin-releasing factor, vasopressin and receptor systems in depression and anxiety," Amino Acids, vol. 31, no. 3, pp. 241-250, 2006.

[63] B. Vollmayr, M. M. Mahlstedt, and F. A. Henn, "Neurogenesis and depression: what animal models tell us about the link," European Archives of Psychiatry and Clinical Neuroscience, vol. 257, no. 5, pp. 300-303, 2007.

[64] D. J. David, B. A. Samuels, Q. Rainer et al., "Neurogenesisdependent and -independent effects of fluoxetine in an animal model of anxiety/depression," Neuron, vol. 62, no. 4, pp. 479493, 2009.

[65] J. M. Bessa, D. Ferreira, I. Melo et al., "The mood-improving actions of antidepressants do not depend on neurogenesis but are associated with neuronal remodeling," Molecular Psychiatry, vol. 14, no. 8, pp. 764-773, 2009.

[66] J. Nacher, M. A. Gomez-Climent, and B. McEwen, "Chronic non-invasive glucocorticoid administration decreases polysialylated neural cell adhesion molecule expression in the adult rat dentate gyrus," Neuroscience Letters, vol. 370, no. 1, pp. 40-44, 2004.

[67] P. Willner, "Chronic mild stress (CMS) revisited: consistency and behavioural- neurobiological concordance in the effects of CMS," Neuropsychobiology, vol. 52, no. 2, pp. 90-110, 2005.

[68] R. M. Sapolsky, M. J. Meaney, and B. S. McEwen, “The development of the glucocorticoid receptor system in the rat limbic brain. III. Negative-feedback regulation," Brain Research, vol. 350, no. 1-2, pp. 169-173, 1985.

[69] R. M. Sapolsky, "Glucocorticoid toxicity in the hippocampus: reversal by supplementation with brain fuels," Journal of Neuroscience, vol. 6, no. 8, pp. 2240-2244, 1986.

[70] R. M. Sapolsky, D. R. Packan, and W. W. Vale, "Glucocorticoid toxicity in the hippocampus: in vitro demonstration," Brain Research, vol. 453, no. 1-2, pp. 367-371, 1988.

[71] Y. I. Sheline, P. W. Wang, M. H. Gado, J. G. Csernansky, and M. W. Vannier, "Hippocampal atrophy in recurrent major depression," Proceedings of the National Academy of Sciences of the United States of America, vol. 93, no. 9, pp. 3908-3913, 1996.

[72] Y. I. Sheline, M. H. Gado, and H. C. Kraemer, "Untreated depression and hippocampal volume loss," American Journal of Psychiatry, vol. 160, no. 8, pp. 1516-1518, 2003. 
[73] M. C. McKinnon, K. Yucel, A. Nazarov, and G. M. MacQueen, "A meta-analysis examining clinical predictors of hippocampal volume in patients with major depressive disorder," Journal of Psychiatry and Neuroscience, vol. 34, no. 1, pp. 41-54, 2009.

[74] J. A. Cobb, J. Simpson, G. J. Mahajan et al., "Hippocampal volume and total cell numbers in major depressive disorder," Journal of Psychiatric Research, vol. 47, no. 3, pp. 299-306, 2013.

[75] M. Boldrini, A. N. Santiago, R. Hen et al., "Hippocampal granule neuron number and dentate gyrus volume in antidepressant-treated and untreated major depression," Neuropsychopharmacology, 2013.

[76] C. A. Stockmeier, G. J. Mahajan, L. C. Konick et al., "Cellular changes in the postmortem hippocampus in major depression," Biological Psychiatry, vol. 56, no. 9, pp. 640-650, 2004.

[77] C. Hercher, G. Turecki, and N. Mechawar, "Through the looking glass: examining neuroanatomical evidence for cellular alterations in major depression," Journal of Psychiatric Research, vol. 43, no. 11, pp. 947-961, 2009.

[78] B. Czéh, T. Welt, A. K. Fischer et al., "Chronic psychosocial stress and concomitant repetitive transcranial magnetic stimulation: effects on stress hormone levels and adult hippocampal neurogenesis," Biological Psychiatry, vol. 52, no. 11, pp. 1057$1065,2002$.

[79] L. A. M. Galea, B. S. McEwen, P. Tanapat, T. Deak, R. L. Spencer, and F. S. Dhabhar, "Sex differences in dendritic atrophy of CA3 pyramidal neurons in response to chronic restraint stress," Neuroscience, vol. 81, no. 3, pp. 689-697, 1997.

[80] Y. Watanabe, E. Gould, and B. S. McEwen, "Stress induces atrophy of apical dendrites of hippocampal CA3 pyramidal neurons," Brain Research, vol. 588, no. 2, pp. 341-345, 1992.

[81] T. J. Shors, C. Chua, and J. Falduto, "Sex differences and opposite effects of stress on dendritic spine density in the male versus female hippocampus," Journal of Neuroscience, vol. 21, no. 16, pp. 6292-6297, 2001.

[82] H. K. Müller, G. Wegener, M. Popoli, and B. Elfving, "Differential expression of synaptic proteins after chronic restraint stress in rat prefrontal cortex and hippocampus," Brain Research, vol. 1385, pp. 26-37, 2011.

[83] B. Czéh, T. Michaelis, T. Watanabe et al., "Stress-induced changes in cerebral metabolites, hippocampal volume, and cell proliferation are prevented by antidepressant treatment with tianeptine," Proceedings of the National Academy of Sciences of the United States of America, vol. 98, no. 22, pp. 12796-12801, 2001.

[84] E. Gould, B. S. McEwen, P. Tanapat, L. A. M. Galea, and E. Fuchs, "Neurogenesis in the dentate gyrus of the adult tree shrew is regulated by psychosocial stress and NMDA receptor activation," Journal of Neuroscience, vol. 17, no. 7, pp. 2492-2498, 1997.

[85] R. Alonso, G. Griebel, G. Pavone, J. Stemmelin, G. Le Fur, and P. Soubrié, "Blockade of CRF1 or V1b receptors reverses stressinduced suppression of neurogenesis in a mouse model of depression," Molecular Psychiatry, vol. 9, no. 3, pp. 278-286, 2004.

[86] J. E. Malberg and R. S. Duman, "Cell proliferation in adult hippocampus is decreased by inescapable stress: reversal by fluoxetine treatment," Neuropsychopharmacology, vol. 28, no. 9, pp. 1562-1571, 2003.

[87] M. Banasr, A. Soumier, M. Hery, E. Mocaër, and A. Daszuta, "Agomelatine, a new antidepressant, induces regional changes in hippocampal neurogenesis," Biological Psychiatry, vol. 59, no. 11, pp. 1087-1096, 2006.

[88] G. Dagyte, A. Trentani, F. Postema et al., "The novel antidepressant agomelatine normalizes hippocampal neuronal activity and promotes neurogenesis in chronically stressed rats," CNS Neuroscience and Therapeutics, vol. 16, no. 4, pp. 195-207, 2010.

[89] T. M. Madsen, A. Treschow, J. Bengzon, T. G. Bolwig, O. Lindvall, and A. Tingström, "Increased neurogenesis in a model of electroconvulsive therapy," Biological Psychiatry, vol. 47, no. 12, pp. 1043-1049, 2000.

[90] J. Hellsten, M. Wennström, P. Mohapel, C. T. Ekdahl, J. Bengzon, and A. Tingström, "Electroconvulsive seizures increase hippocampal neurogenesis after chronic corticosterone treatment," European Journal of Neuroscience, vol. 16, no. 2, pp. 283290, 2002.

[91] D. Pagnin, V. De Queiroz, S. Pini, and G. B. Cassano, "Efficacy of ECT in depression: a meta-analytic review," Journal of ECT, vol. 20, no. 1, pp. 13-20, 2004.

[92] A. Surget, M. Saxe, S. Leman et al., "Drug-dependent requirement of hippocampal neurogenesis in a model of depression and of antidepressant reversal," Biological Psychiatry, vol. 64, no. 4, pp. 293-301, 2008.

[93] K. A. Holick, D. C. Lee, R. Hen, and S. C. Dulawa, "Behavioral effects of chronic fluoxetine in BALB/CJ mice do not require adult hippocampal neurogenesis or the serotonin $1 \mathrm{~A}$ receptor," Neuropsychopharmacology, vol. 33, no. 2, pp. 406-417, 2008.

[94] R. D. Airan, L. A. Meltzer, M. Roy, Y. Gong, H. Chen, and K. Deisseroth, "High-speed imaging reveals neurophysiological links to behavior in an animal model of depression," Science, vol. 317, no. 5839, pp. 819-823, 2007.

[95] S. R. Bodnoff, B. Suranyi-Cadotte, R. Quirion, and M. J. Meaney, "A comparison of the effects of diazepam versus several typical and atypical anti-depressant drugs in an animal model of anxiety," Psychopharmacology, vol. 97, no. 2, pp. 277-279, 1989.

[96] J. S. Snyder, A. Soumier, M. Brewer, J. Pickel, and H. A. Cameron, "Adult hippocampal neurogenesis buffers stress responses and depressive behaviour," Nature, vol. 476, no. 7361, pp. 458-461, 2011.

[97] T. McCall, Z. M. Weil, J. Nacher et al., "Depletion of polysialic acid from neural cell adhesion molecule (PSA-NCAM) increases CA3 dendritic arborization and increases vulnerability to excitotoxicity," Experimental Neurology, vol. 241, pp. 5-12, 2013.

[98] T. Seki and U. Rutishauser, "Removal of polysialic acid-neural cell adhesion molecule induces aberrant mossy fiber innervation and ectopic synaptogenesis in the hippocampus," Journal of Neuroscience, vol. 18, no. 10, pp. 3757-3766, 1998.

[99] B. Seri, J. M. García-Verdugo, L. Collado-Morente, B. S. McEwen, and A. Alvarez-Buylla, "Cell types, lineage, and architecture of the germinal zone in the adult dentate gyrus," Journal of Comparative Neurology, vol. 478, no. 4, pp. 359-378, 2004.

[100] C. M. Ni Dhuill, G. B. Fox, S. J. Pittock, A. W. O'Connell, K. J. Murphy, and C. M. Regan, "Polysialylated neural cell adhesion molecule expression in the dentate gyrus of the human hippocampal formation from infancy to old age," Journal of Neuroscience Research, vol. 55, no. 1, pp. 99-106, 1999.

[101] H. G. Kuhn, H. Dickinson-Anson, and F. H. Gage, "Neurogenesis in the dentate gyrus of the adult rat: age-related decrease of neuronal progenitor proliferation," Journal of Neuroscience, vol. 16, no. 6, pp. 2027-2033, 1996.

[102] G. B. Fox, N. Kennedy, and C. M. Regan, "Polysialylated neural cell adhesion molecule expression by neurons and astroglial processes in the rat dentate gyrus declines dramatically with increasing age," International Journal of Developmental Neuroscience, vol. 13, no. 7, pp. 663-672, 1995.

[103] T. Seki and Y. Arai, "Highly polysialylated neural cell adhesion molecule (NCAM-H) is expressed by newly generated granule 
cells in the dentate gyrus of the adult rat," Journal of Neuroscience, vol. 13, no. 6, pp. 2351-2358, 1993.

[104] T. Seki and Y. Arai, "The persistent expression of a highly polysialylated NCAM in the dentate gyrus of the adult rat," Neuroscience Research, vol. 12, no. 4, pp. 503-513, 1991.

[105] M. I. Cordero, J. J. Rodríguez, H. A. Davies, C. J. Peddie, C. Sandi, and M. G. Stewart, "Chronic restraint stress down-regulates amygdaloid expression of polysialylated neural cell adhesion molecule," Neuroscience, vol. 133, no. 4, pp. 903-910, 2005.

[106] J. Nacher, K. Pham, V. Gil-Fernandez, and B. S. Mcewen, "Chronic restraint stress and chronic corticosterone treatment modulate differentially the expression of molecules related to structural plasticity in the adult rat piriform cortex," Neuroscience, vol. 126, no. 2, pp. 503-509, 2004.

[107] K. Pham, J. Nacher, P. R. Hof, and B. S. McEwen, "Repeated restraint stress suppresses neurogenesis and induces biphasic PSA-NCAM expression in the adult rat dentate gyrus," European Journal of Neuroscience, vol. 17, no. 4, pp. 879-886, 2003.

[108] C. Sandi, J. J. Merino, M. I. Cordero, K. Touyarot, and C. Venero, "Effects of chronic stress on contextual fear conditioning and the hippocampal expression of the neural cell adhesion molecule, its polysialylation, and L1," Neuroscience, vol. 102, no. 2, pp. 329-339, 2001.

[109] A. Djordjevic, J. Djordjevic, I. Elakovic, M. Adzic, G. Matic, and M. B. Radojcic, "Fluoxetine affects hippocampal plasticity, apoptosis and depressive-like behavior of chronically isolated rats," Prog Neuropsychopharmacol Biol Psychiatry, vol. 36, no. 1, pp. 92-100, 2012.

[110] J. Gilabert-Juan, E. Castillo-Gomez, R. Guirado, M. D. Molto, and J. Nacher, "Chronic stress alters inhibitory networks in the medial prefrontal cortex of adult mice," Brain Structure and Function, 2012.

[111] J. Djordjevic, A. Djordjevic, M. Adzic, and M. B. Radojcic, "Effects of chronic social isolation on Wistar rat behavior and brain plasticity markers," Neuropsychobiology, vol. 66, no. 2, pp. 112-119, 2012.

[112] A. Djordjevic, J. Djordjevic, I. Elakovic, M. Adzic, G. Matic, and M. B. Radojcic, "Effects of fluoxetine on plasticity and apoptosis evoked by chronic stress in rat prefrontal cortex," European Journal of Pharmacology, vol. 693, no. 1-3, pp. 37-44, 2012.

[113] J. Gilabert-Juan, E. Castillo-Gomeza, M. Pérez-Randoa, M. Dolores Moltab, and J. Nachera, "Chronic stress induces changes in the structure of interneurons and in the expression of molecules related to neuronal structural plasticity and inhibitory neurotransmission in the amygdala of adult mice," Experimental Neurology, vol. 232, no. 1, pp. 33-40, 2011.

[114] M. E. Maheu, M. A. Davoli, G. Turecki, and N. Mechawar, "Amygdalar expression of proteins associated with neuroplasticity in major depression and suicide," Journal of Psychiatric Research, vol. 47, no. 3, pp. 384-390, 2013.

[115] J. Gilabert-Juan, E. Varea, R. Guirado, J. M. Blasco-Ibanez, C. Crespo, and J. Nacher, "Alterations in the expression of PSANCAM and synaptic proteins in the dorsolateral prefrontal cortex of psychiatric disorder patients," Neuroscience Letters, vol. 530, no. 1, pp. 97-102, 2012.

[116] J. R. Homberg, J. D. A. Olivier, T. Blom et al., "Fluoxetine exerts age-dependent effects on behavior and amygdala neuroplasticity in the rat," PLoS ONE, vol. 6, no. 1, Article ID e16646, 2011.

[117] E. Varea, E. Castillo-Gómez, M. A. Gómez-Climent et al., "Chronic antidepressant treatment induces contrasting patterns of synaptophysin and PSA-NCAM expression in different regions of the adult rat telencephalon," European Neuropsychopharmacology, vol. 17, no. 8, pp. 546-557, 2007.

[118] M. Sairanen, O. F. O’Leary, J. E. Knuuttila, and E. Castrén, "Chronic antidepressant treatment selectively increases expression of plasticity-related proteins in the hippocampus and medial prefrontal cortex of the rat," Neuroscience, vol. 144, no. 1, pp. 368-374, 2007.

[119] E. Varea, J. M. Blasco-Ibáñez, M. Á. Gómez-Climent et al., "Chronic fluoxetine treatment increases the expression of PSANCAM in the medial prefrontal cortex," Neuropsychopharmacology, vol. 32, no. 4, pp. 803-812, 2007.

[120] J. J. Rodríguez, G. M. Dallérac, M. Tabuchi et al., "N-methyl$\mathrm{d}$-aspartate receptor independent changes in expression of polysialic acid-neural cell adhesion molecule despite blockade of homosynaptic long-term potentiation and heterosynaptic long-term depression in the awake freely behaving rat dentate gyrus," Neuron Glia Biology, vol. 4, no. 3, pp. 169-178, 2008.

[121] G. Guiraudie-Capraz, F. A. Chaillan, B. Truchet, J. L. Franc, C. Mourre, and F. S. Roman, "Increase in polysialyltransferase gene expression following LTP in adult rat dentate gyrus," Hippocampus, vol. 21, no. 11, pp. 1180-1189, 2011.

[122] D. Muller, P. Mendez, M. DeRoo, P. Klauser, S. Steen, and L. Poglia, "Role of NCAM in Spine dynamics and synaptogenesis," Advances in Experimental Medicine and Biology, vol. 663, pp. 245-256, 2010.

[123] M. Grzegorzewska, M. Maćkowiak, K. Wedzony, and G. Hess, "5-HT1A receptors mediate detrimental effects of cocaine on long-term potentiation and expression of polysialylated neural cell adhesion molecule protein in rat dentate gyrus," Neuroscience, vol. 166, no. 1, pp. 122-131, 2010.

[124] J. M. Brezun and A. Daszuta, "Serotonergic reinnervation reverses lesion-induced decreases in PSA-NCAM labeling and proliferation of hippocampal cells in adult rats," Hippocampus, vol. 10, no. 1, pp. 37-46, 2000.

[125] F. Karege, G. Perret, G. Bondolfi, M. Schwald, G. Bertschy, and J. M. Aubry, "Decreased serum brain-derived neurotrophic factor levels in major depressed patients," Psychiatry Research, vol. 109, no. 2, pp. 143-148, 2002.

[126] E. Shimizu, K. Hashimoto, N. Okamura et al., "Alterations of serum levels of brain-derived neurotrophic factor (BDNF) in depressed patients with or without antidepressants," Biological Psychiatry, vol. 54, no. 1, pp. 70-75, 2003.

[127] O. Aydemir, A. Deveci, and F. Taneli, "The effect of chronic antidepressant treatment on serum brain-derived neurotrophic factor levels in depressed patients: a preliminary study," Progress in Neuro-Psychopharmacology and Biological Psychiatry, vol. 29, no. 2, pp. 261-265, 2005.

[128] Y. Shirayama, A. C. H. Chen, S. Nakagawa, D. S. Russell, and R. S. Duman, "Brain-derived neurotrophic factor produces antidepressant effects in behavioral models of depression," Journal of Neuroscience, vol. 22, no. 8, pp. 3251-3261, 2002.

[129] J. Grønli, C. Bramham, R. Murison et al., "Chronic mild stress inhibits BDNF protein expression and CREB activation in the dentate gyrus but not in the hippocampus proper," Pharmacology Biochemistry and Behavior, vol. 85, no. 4, pp. 842-849, 2006.

[130] C. A. Altar, R. E. Whitehead, R. Chen, G. Wörtwein, and T. M. Madsen, "Effects of electroconvulsive seizures and antidepressant drugs on brain-derived neurotrophic factor protein in rat brain," Biological Psychiatry, vol. 54, no. 7, pp. 703-709, 2003.

[131] J. Vinet, S. Carra, J. M. C. Blom, N. Brunello, N. Barden, and F. Tascedda, "Chronic treatment with desipramine and fluoxetine 
modulate BDNF, CaMKK $\alpha$ and CaMKK $\beta$ mRNA levels in the hippocampus of transgenic mice expressing antisense RNA against the glucocorticoid receptor," Neuropharmacology, vol. 47, no. 7, pp. 1062-1069, 2004.

[132] A. Russo-Neustadt, R. C. Beard, and C. W. Cotman, "Exercise, antidepressant medications, and enhanced brain derived neurotrophic factor expression," Neuropsychopharmacology, vol. 21, no. 5, pp. 679-682, 1999.

[133] J. A. Siuciak, D. R. Lewis, S. J. Wiegand, and R. M. Lindsay, "Antidepressant-like effect of brain-derived neurotrophic factor (BDNF)," Pharmacology Biochemistry and Behavior, vol. 56, no. 1, pp. 131-137, 1996.

[134] S. C. Danzer, K. R. C. Crooks, D. C. Lo, and J. O. McNamara, "Increased expression of brain-derived neurotrophic factor induces formation of basal dendrites and axonal branching in dentate granule cells in hippocampal explant cultures," Journal of Neuroscience, vol. 22, no. 22, pp. 9754-9763, 2002.

[135] F. J. Seil and R. Drake-Baumann, "TrkB receptor ligands promote activity-dependent inhibitory synaptogenesis," Journal of Neuroscience, vol. 20, no. 14, pp. 5367-5373, 2000.

[136] Y. Li, B. W. Luikart, S. Birnbaum et al., "TrkB regulates Hippocampal neurogenesis and governs sensitivity to antidepressive treatment," Neuron, vol. 59, no. 3, pp. 399-412, 2008.

[137] E. Castrén and T. Rantamäki, "The role of BDNF and its receptors in depression and antidepressant drug action: reactivation of developmental plasticity," Developmental Neurobiology, vol. 70, no. 5, pp. 289-297, 2010.

[138] B. Zörner, D. P. Wolfer, D. Brandis et al., "Forebrain-specific trkB-receptor knockout mice: behaviorally more hyperactive than 'depressive,' Biological Psychiatry, vol. 54, no. 10, pp. 972982, 2003.

[139] T. Saarelainen, P. Hendolin, G. Lucas et al., "Activation of the TrkB neurotrophin receptor is induced by antidepressant drugs and is required for antidepressant-induced behavioral effects," Journal of Neuroscience, vol. 23, no. 1, pp. 349-357, 2003.

[140] L. M. Monteggia, B. Luikart, M. Barrot et al., "Brain-derived neurotrophic factor conditional knockouts show gender differences in depression-related behaviors," Biological Psychiatry, vol. 61, no. 2, pp. 187-197, 2007.

[141] D. Muller, Z. Djebbara-Hannas, P. Jourdain et al., "Brainderived neurotrophic factor restores long-term potentiation in polysialic acid-neural cell adhesion molecule-deficient hippocampus," Proceedings of the National Academy of Sciences of the United States of America, vol. 97, no. 8, pp. 4315-4320, 2000.

[142] L. Vutskits, Z. Djebbara-Hannas, H. Zhang et al., "PSA-NCAM modulates BDNF-dependent survival and differentiation of cortical neurons," European Journal of Neuroscience, vol. 13, no. 7, pp. 1391-1402, 2001.

[143] A. Burgess and I. Aubert, "Polysialic acid limits choline acetyltransferase activity induced by brain-derived neurotrophic factor," Journal of Neurochemistry, vol. 99, no. 3, pp. 797-806, 2006.

[144] E. Gascon, L. Vutskits, B. Jenny, P. Durbec, and J. Z. Kiss, "PSA-NCAM in postnatally generated immature neurons of the olfactory bulb: a crucial role in regulating p75 expression and cell survival," Development, vol. 134, no. 6, pp. 1181-1190, 2007.

[145] K. M. Young, T. D. Merson, A. Sotthibundhu, E. J. Coulson, and P. F. Bartlett, "p75 neurotrophin receptor expression defines a population of BDNF-responsive neurogenic precursor cells," Journal of Neuroscience, vol. 27, no. 19, pp. 5146-5155, 2007.

[146] V. S. Catts, N. Al-Menhali, T. H. J. Burne, M. J. Colditz, and E. J. Coulson, “The p75 neurotrophin receptor regulates hippocampal neurogenesis and related behaviours," European Journal of Neuroscience, vol. 28, no. 5, pp. 883-892, 2008.

[147] M. J. Colditz, V. S. Catts, N. Al-Menhali, G. W. Osborne, P. F. Bartlett, and E. J. Coulson, "P75 neurotrophin receptor regulates basal and fluoxetine-stimulated hippocampal neurogenesis," Experimental Brain Research, vol. 200, no. 2, pp. 161-167, 2010.

[148] K. Gutiérrez-Lobos, M. Scherer, P. Anderer, and H. Katschnig, "The influence of age on the female/male ratio of treated incidence rates in depression," BMC Psychiatry, vol. 2, no. 1, p. 3, 2002.

[149] S. G. Kornstein, A. F. Schatzberg, M. E. Thase et al., "Gender differences in treatment response to sertraline versus imipramine in chronic depression," American Journal of Psychiatry, vol. 157, no. 9, pp. 1445-1452, 2000.

[150] M. M. Shores, K. L. Sloan, A. M. Matsumoto, V. M. Moceri, B. Felker, and D. R. Kivlahan, "Increased incidence of diagnosed depressive illness in hypogonadal older men," Archives of General Psychiatry, vol. 61, no. 2, pp. 162-167, 2004.

[151] M. M. Shores, V. M. Moceri, K. L. Sloan, A. M. Matsumoto, and D. R. Kivlahan, "Low testosterone levels predict incident depressive illness in older men: effects of age and medical morbidity," The Journal of clinical psychiatry, vol. 66, no. 1, pp. 7-14, 2005.

[152] M. M. Shores, D. R. Kivlahan, T. I. Sadak, E. J. Li, and A. M. Matsumoto, "A randomized, double-blind, placebo-controlled study of testosterone treatment in hypogonadal older men with subthreshold depression (dysthymia or minor depression)," Journal of Clinical Psychiatry, vol. 70, no. 7, pp. 1009-1016, 2009.

[153] R. S. McIntyre, D. Mancini, B. S. Eisfeld et al., "Calculated bioavailable testosterone levels and depression in middle-aged men," Psychoneuroendocrinology, vol. 31, no. 9, pp. 1029-1035, 2006.

[154] A. B. Veras and A. E. Nardi, "The complex relationship between hypogonadism and major depression in a young male," Progress in Neuro-Psychopharmacology and Biological Psychiatry, vol. 34, no. 2, pp. 421-422, 2010.

[155] S. N. Seidman and J. G. Rabkin, "Testosterone replacement therapy for hypogonadal men with SSRI- refractory depression," Journal of Affective Disorders, vol. 48, no. 2-3, pp. 157-161, 1998.

[156] F. A. Zarrouf, S. Artz, J. Griffith, C. Sirbu, and M. Kommor, "Testosterone and depression: systematic review and metaanalysis," Journal of Psychiatric Practice, vol. 15, no. 4, pp. 289305, 2009.

[157] H. G. Pope Jr., G. H. Cohane, G. Kanayama, A. J. Siegel, and J. I. Hudson, "Testosterone gel supplementation for men with refractory depression: a randomized, placebo-controlled trial," American Journal of Psychiatry, vol. 160, no. 1, pp. 105-111, 2003.

[158] S. N. Seidman, E. Spatz, C. Rizzo, and S. P. Roose, "Testosterone replacement therapy for hypogonadal men with major depressive disorder: a randomized, placebo-controlled clinical trial," Journal of Clinical Psychiatry, vol. 62, no. 6, pp. 406-412, 2001.

[159] H. G. Pope Jr., R. Amiaz, B. P. Brennan et al., "Parallel-group placebo-controlled trial of testosterone gel in men with major depressive disorder displaying an incomplete response to standard antidepressant treatment," Journal of Clinical Psychopharmacology, vol. 30, no. 2, pp. 126-134, 2010.

[160] V. Hendrick, L. L. Altshuler, and R. Suri, "Hormonal changes in the postpartum and implications for postpartum depression," Psychosomatics, vol. 39, no. 2, pp. 93-101, 1998.

[161] L. S. Cohen, C. N. Soares, A. F. Vitonis, M. W. Otto, and B. L. Harlow, "Risk for new onset of depression during the menopausal transition: the harvard study of moods and cycles," Archives of General Psychiatry, vol. 63, no. 4, pp. 385-390, 2006. 
[162] N. L. Rasgon, L. L. Altshuler, L. A. Fairbanks et al., "Estrogen replacement therapy in the treatment of major depressive disorder in perimenopausal women," Journal of Clinical Psychiatry, vol. 63, supplement 7, pp. 45-48, 2002.

[163] C. De Novaes Soares, O. P. Almeida, H. Joffe, and L. S. Cohen, "Efficacy of estradiol for the treatment of depressive disorders in perimenopausal women: a double-blind, randomized, placebocontrolled trial," Archives of General Psychiatry, vol. 58, no. 6, pp. 529-534, 2001.

[164] C. N. Soares, J. R. Poitras, J. Prouty, A. B. Alexander, J. L. Shifren, and L. S. Cohen, "Efficacy of citalopram as a monotherapy or as an adjunctive treatment to estrogen therapy for perimenopausal and postmenopausal women with depression and vasomotor symptoms," Journal of Clinical Psychiatry, vol. 64, no. 4, pp. 473479, 2003.

[165] A. D. Green and L. A. M. Galea, "Adult hippocampal cell proliferation is suppressed with estrogen withdrawal after a hormone-simulated pregnancy," Hormones and Behavior, vol. 54, no. 1, pp. 203-211, 2008.

[166] S. L. Sell, R. M. Craft, P. K. Seitz, S. J. Stutz, K. A. Cunningham, and M. L. Thomas, "Estradiol-sertraline synergy in ovariectomized rats," Psychoneuroendocrinology, vol. 33, no. 8, pp. 10511060, 2008.

[167] N. Carrier and M. Kabbaj, "Testosterone and imipramine have antidepressant effects in socially isolated male but not female rats," Hormones and Behavior, vol. 61, no. 5, pp. 678-685, 2012.

[168] M. D. Spritzer and L. A. M. Galea, "Testosterone and dihydrotestosterone, but not estradiol, enhance survival of new hippocampal neurons in adult male rats," Developmental Neurobiology, vol. 67, no. 10, pp. 1321-1333, 2007.

[169] L. A. M. Galea, M. D. Spritzer, J. M. Barker, and J. L. Pawluski, "Gonadal hormone modulation of hippocampal neurogenesis in the adult," Hippocampus, vol. 16, no. 3, pp. 225-232, 2006.

[170] O. Tan, A. Fadiel, A. Chang et al., "Estrogens regulate posttranslational modification of neural cell adhesion molecule during the estrogen-induced gonadotropin surge," Endocrinology, vol. 150, no. 6, pp. 2783-2790, 2009.

[171] Y. Hatanaka, H. Mukai, K. Mitsuhashi et al., "Androgen rapidly increases dendritic thorns of CA3 neurons in male rat hippocampus," Biochemical and Biophysical Research Communications, vol. 381, no. 4, pp. 728-732, 2009.

[172] N. J. MacLusky, T. Hajszan, J. A. Johansen, C. L. Jordan, and C. Leranth, "Androgen effects on hippocampal CA1 spine synapse numbers are retained in Tfm male rats with defective androgen receptors," Endocrinology, vol. 147, no. 5, pp. 2392-2398, 2006.

[173] S. Rasika, A. Alvarez-Buylla, and F. Nottebohm, "BDNF mediates the effects of testosterone on the survival of new neurons in an adult brain," Neuron, vol. 22, no. 1, pp. 53-62, 1999.

[174] L. Y. Yang, T. Verhovshek, and D. R. Sengelaub, "Brain-derived neurotrophic factor and androgen interact in the maintenance of dendritic morphology in a sexually dimorphic rat spinal nucleus," Endocrinology, vol. 145, no. 1, pp. 161-168, 2004.

[175] D. T. Solum and R. J. Handa, "Estrogen regulates the development of Brain-derived neurotrophic factor mRNA and protein in the rat hippocampus," Journal of Neuroscience, vol. 22, no. 7, pp. 2650-2659, 2002.

[176] T. B. Franklin and T. S. Perrot-Sinal, "Sex and ovarian steroids modulate brain-derived neurotrophic factor (BDNF) protein levels in rat hippocampus under stressful and non-stressful conditions," Psychoneuroendocrinology, vol. 31, no. 1, pp. 38-48, 2006.
[177] F. Sohrabji, R. C. G. Miranda, and C. D. Toran-Allerand, "Identification of a putative estrogen response element in the gene encoding brain-derived neurotrophic factor," Proceedings of the National Academy of Sciences of the United States of America, vol. 92, no. 24, pp. 11110-11114, 1995.

[178] D. D. Murphy, N. B. Cole, and M. Segal, "Brain-derived neurotrophic factor mediates estradiol-induced dendritic spine formation in hippocampal neurons," Proceedings of the National Academy of Sciences of the United States of America, vol. 95, no. 19, pp. 11412-11417, 1998.

[179] Y. Dimberg, M. Vazquez, S. Söderström, and T. Ebendal, "Effects of X-irradiation on nerve growth factor in the developing mouse brain," Toxicology Letters, vol. 90, no. 1, pp. 35-43, 1997.

[180] G. Casadesus, B. Shukitt-Hale, H. M. Stellwagen, M. A. Smith, B. M. Rabin, and J. A. Joseph, "Hippocampal neurogenesis and PSA-NCAM expression following exposure to 56Fe particles mimics that seen during aging in rats," Experimental Gerontology, vol. 40, no. 3, pp. 249-254, 2005.

[181] J. S. Snyder, J. S. Choe, M. A. Clifford et al., "Adult-born hippocampal neurons are more numerous, faster maturing, and more involved in behavior in rats than in mice," Journal of Neuroscience, vol. 29, no. 46, pp. 14484-14495, 2009.

[182] W. N. Marsden, "Synaptic plasticity in depression: molecular, cellular and functional correlates," Progress in Neuro-Psychopharmacology Biological Psychiatry C, vol. 43, pp. 168-184, 2012.

[183] C. Sandi and R. Bisaz, "A model for the involvement of neural cell adhesion molecules in stress-related mood disorders," Neuroendocrinology, vol. 85, no. 3, pp. 158-176, 2007. 

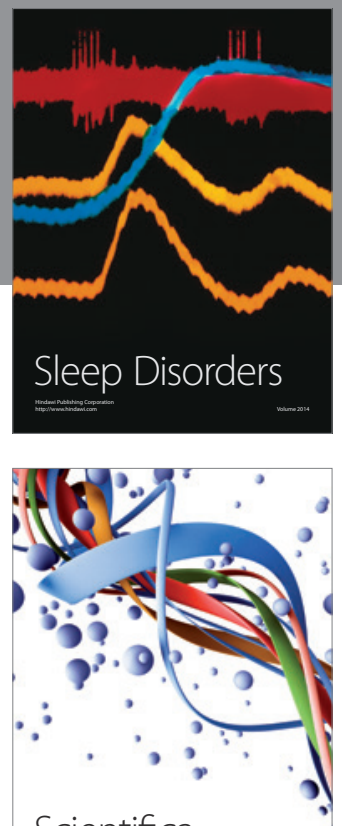

Scientifica
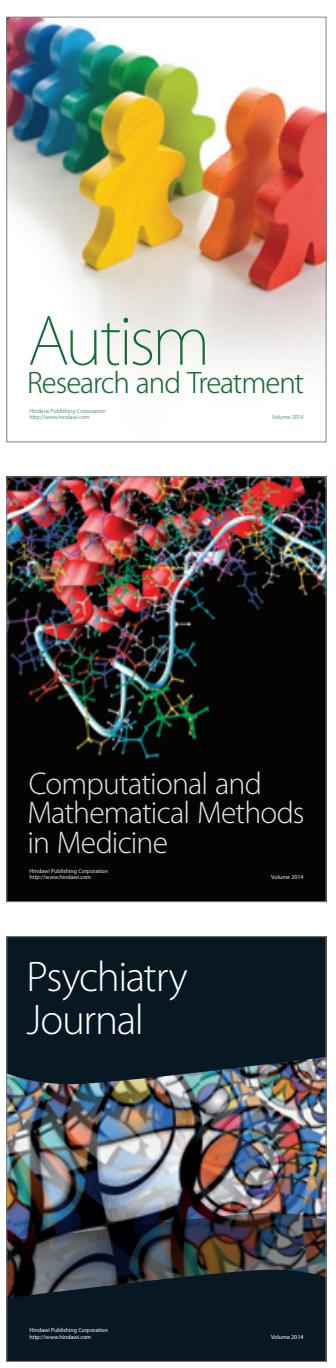
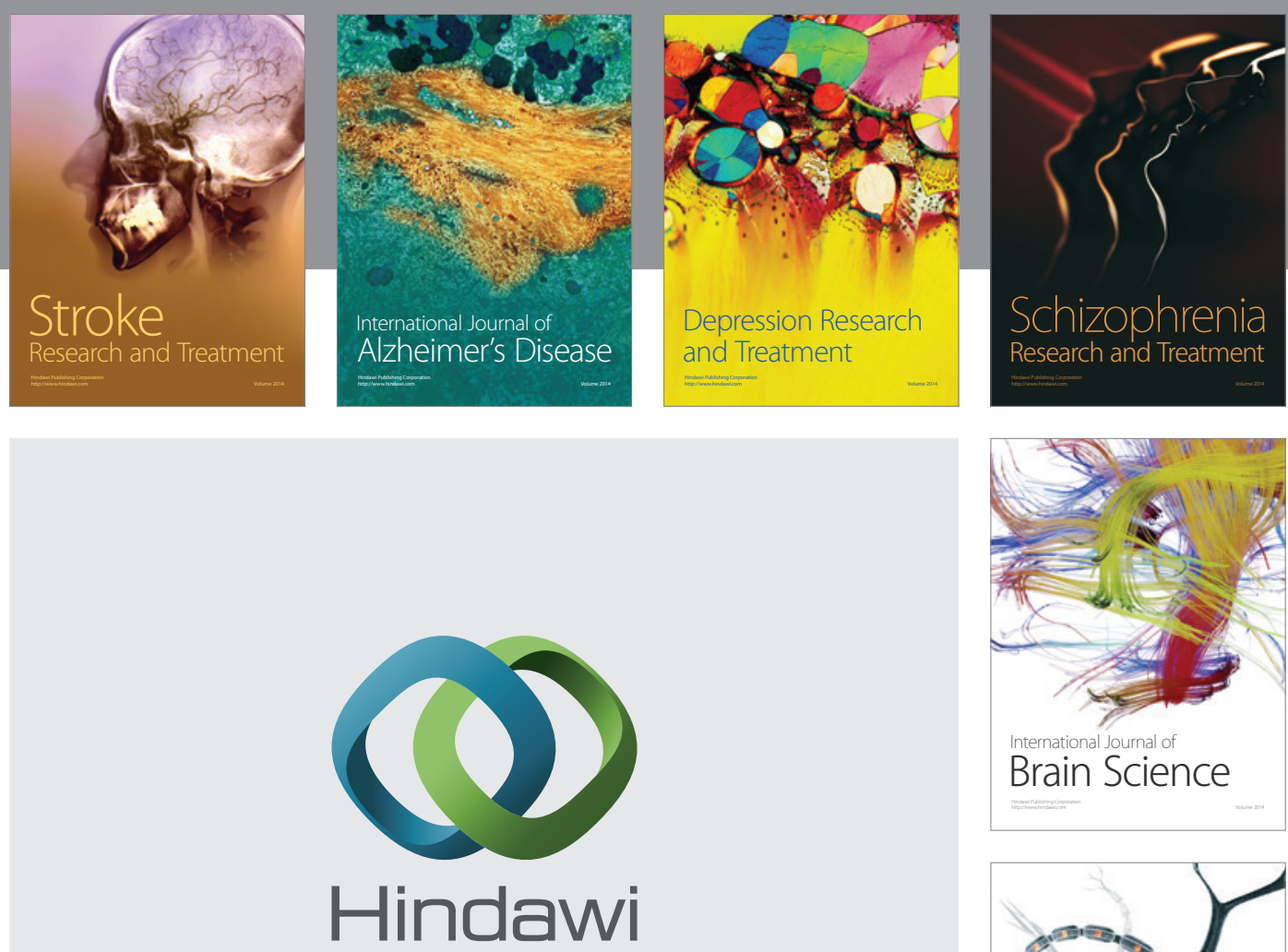

Submit your manuscripts at

http://www.hindawi.com
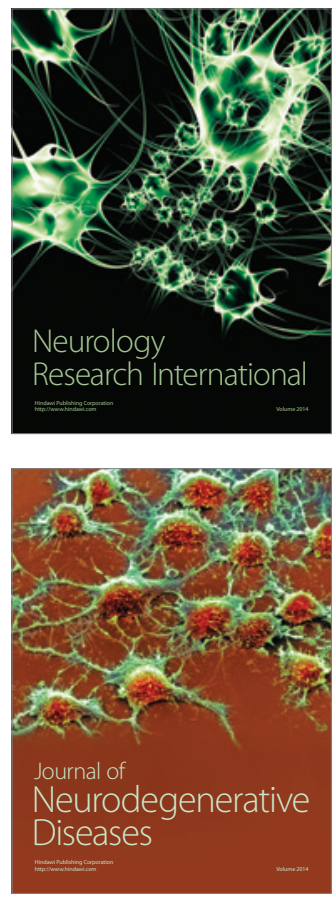

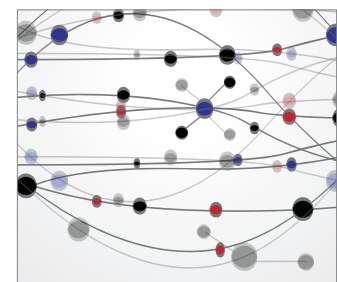

The Scientific World Journal
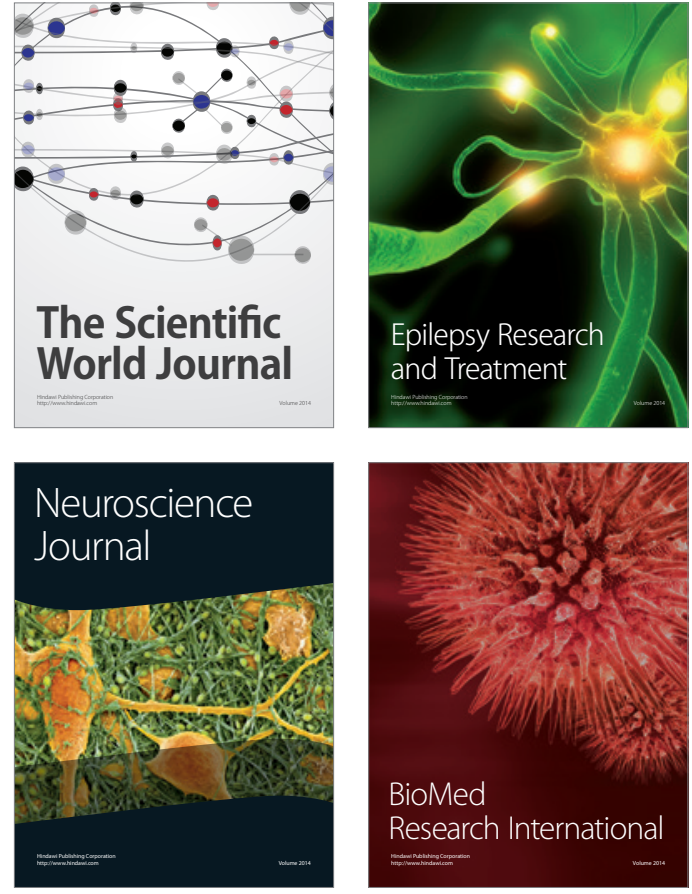

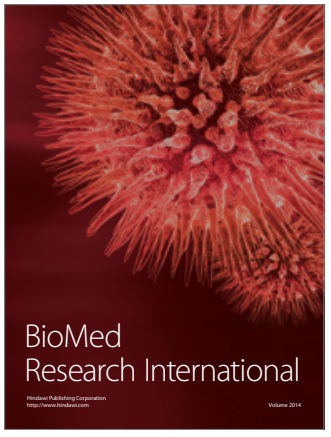

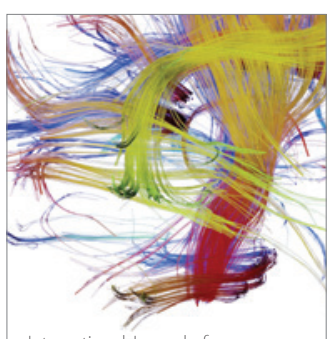

Brain Science

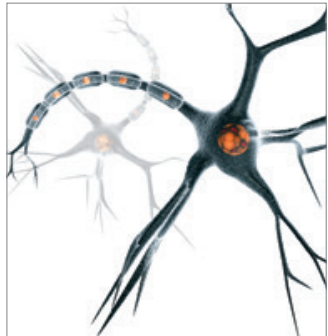

Neural Plasticity
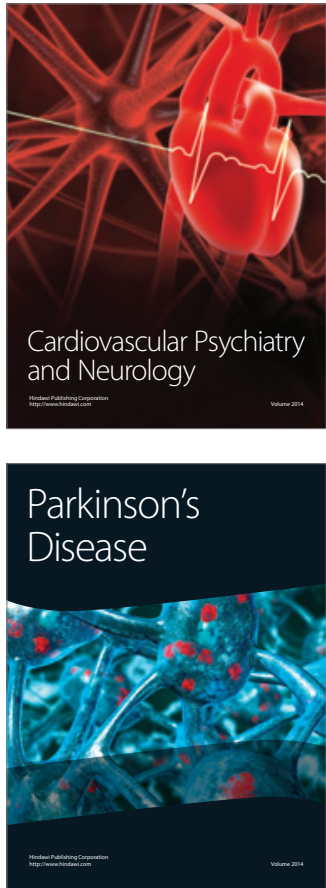